\title{
Researches on Coprophilous Fungi.
}

\author{
GEORGE MASSEE, F.L.S., \\ Herbarium, Royal Gardens, Kerw,
}

AND

ERNEST S. SALMON, F.L.S.

\section{With Plates XVII and XVIII.}

TNTIL recently the systematic side of Mycology has received most attention in Britain, a fact which probably accounts for the absence of any specific work on Coprophilous or dung-borne Fungi, many of which, as the species of Gymnoascus, Thelebolus, Microascus, \&c., on account of being the most primitive representatives of their respective groups, are perhaps more interesting from a morphological than a purely systematic standpoint. A second reason may lie in the fact that many of the species are so very minute that their presence cannot be detected in the field; in fact it is only after considerable experience that they can be seen under the most favourable conditions of illumination, and as their duration is in many instances ephemeral the only chance of success is by keeping the material upon which they grow in the laboratory, where a daily examination can be made. Even from a systematic standpoint our investigations have shown that a careful study of the Fungi growing on the dung

[Annals of Botany, Vol. XV. No. LVIII. June, 1 gor.] 
of various animals will in all probability add many interesting species to our Mycologic Flora.

In many continental countries this special branch of Mycology has not been neglected, excellent work having been done by Hansen (I 5 ) in Denmark; Boudier (4) and Crouan (II, I2) in France; Coemans $(8,9)$ and Marchal $(20)$ in Belgium; Spegazzini (37) in Italy; Heimerl ( 17 ) and Zukal $(5 \circ-54)$ in Austria; Winter $(4 \mathrm{I}-45)$ and Zopf $(47-49)$ in Germany; Karsten (19) in Finland, and Chelchowski (7) in Poland.

\section{Morphology, Spore-Germination, EtC.}

As coprophilous Fungi do not form a concrete group they cannot be treated from a comparative point of view, nevertheless certain structural features claim attention. The most typical of ascigerous coprophilous Fungi are those included in the Sordarieae and the Ascoboleae, and as already noted of dung-borne Fungi, when treating of the genus Coprinus in this Journal (22), the spores in both these groups are as a rule comparatively large and deeply coloured-characteristics of a primitive type; in the genera Ascobolus and Saccobolus the spores-as in every Fungus-are hyaline when young, subsequently the epispore passes from pale lilac through bright violet to deep brown, the final colouration in many instances becoming so intense as to render the spore opaque when viewed by transmitted light. In the Sordarieae the spores are always dark brown and often quite opaque-hence appearing black at maturity.

In some species of Ascobolus each spore is surrounded by a hyaline mucilaginous layer, whereas in Saccobolus the four or eight spores contained in an ascus are agglutinated together at maturity, in a definite manner for each species, by a mass of mucilage (Figs. 50, 5I). This massing together of the spores in the ascus is the one feature that distinguishes the genus Saccobolus from Ascobolus. It is, however, in species of the Sordarieae that the presence of hyaline mucilage on the spores reaches its fullest development. In many species the 
mucilage forms a uniform sheath enclosing the entire spore (Figs. 9, 10), appearing under the microscope as a hyaline refractive peripheral belt or zone, varying in width in different species. In other species of Sordaria the spores first appear as eight hyaline vermiform bodies each nearly as long as the ascus (Fig. 8). At a later stage a swelling appears near the apex of each spore (Fig. 8); this swelling continues to increase in size and absorbs the protoplasm from the slender portion below, which is eventually cut off by a septum from the swollen portion or spore proper. Eventually the spore becomes coloured, while the basal portion remains colourless and forms an appendage. Appendages formed in this manner have a cellulose wall, and in rare instances the septum cutting off the cavity of the spore from that of the appendage is not developed, when the wall of the latter becomes coloured like that of the spore, thus proving that the colouration of the epispore depends on the presence of living protoplasm in the cell. We have observed this phenomenon repeatedly in Sordaria globosa, and it has also been noted by Hansen (I5) in an undetermined species of Sordaria.

In addition to the appendage described above, a second kind consisting of mucilage is also often present. Such an appendage may be attached to the apex or base, or to both ends of the spore (Fig. I5), or even to the end of the primary appendage which is cut off from the young spore as described above (Fig. I6). These mucilaginous appendages usually disappear when the spore reaches maturity; they become much swollen and eventually deliquesce in contact with water, and stain readily with methylene blue. In the two species of Xylaria growing on dung the spores are of very large size and surrounded by a broad zone of mucilage, whereas in the numerous other species of Xylaria growing on wood, \&c., the spores are usually minute and always destitute of a mucilaginous external layer.

Zopf (48) considers that the mucilaginous appendages of the spores are formed from the protoplasm in the ascus not used up in the formation of the spores, and also suggests that 
the appendages serve to keep the spores in their relative positions in the ascus, and states that in some Sordarieae the uppermost spore is attached to the apex of the ascus.

In species of Ascobolus, Ryparobius, Saccobolus, Sordaria, and Thelebolus we have observed that at maturity the spores are ejected in an agglutinated mass, often to a considerable distance. This ejection occurs equally in bright sunshine or in darkness. The sudden shooting out of the spores from the ascus appears to depend on the absorption of moisture by the mucus and consequent increase of volume. When a section of an ascophore containing mature spores is examined in the dry state no change occurs, but when water is applied the mucus in the asci is seen to swell and the spores are suddenly shot forth. If alcohol is used instead of water the spores do not move. In the species of Chaetomium and in Spumatoria the asci deliquesce and the mucus thus formed swells by the absorption of water and escapes, carrying the spores along with it, through the mouth of the perithecium, where it forms a ball which persists for some time until dissolved by rain or dew.

Attempts on the part of De Bary (13), Brefeld (6), and Janczewski (18) to germinate Ascobolus spores resulted in failure, and the opinion is generally entertained that a passage through the intestinal canal of an animal is necessary to induce germination. The last-named author fed rabbits with bread containing Ascobolus spores, and observed that germination had commenced when the dung was deposited. Our experiments have proved that Ascobolus spores will germinate without passing through the intestinal canal, nevertheless. we believe that the majority of the spores of species of Ascobolus that eventually produce fruit on dung have been swallowed along with food by herbivorous animals.

When the spores of species of Ascobolus are ejected, the mucus that holds them in a group sets firmly immediately on exposure to the air into a mass almost insoluble in water. For the purpose of obtaining pure sowings of spores, dung, bearing Fungi of the species required, was enclosed in a Petri 
dish. At the expiration of two or three hours, numerous groups, each containing eight spores, were deposited on the lid of the dish, and so firmly cemented that they could not be removed with a needle without breaking the mass to powder. When such pure deposits of spores are secured it is only necessary to add a nutritive medium for the purpose of studying germination. When spores so deposited have been immersed for a week in liquid they still remain in groups firmly cemented to the glass. The spore-masses ejected by Thelebolus stercoreus behave in a similar manner.

The above experiments prove that the wholesale diffusion of Ascobolus spores by wind is out of the question, and the explanation of the presence of species of Ascobolus on practically every portion of dung deposited seems to be that the spores from the Fungi on a given piece of dung are ejected and alight on the surrounding grass. Such spore-laden grass is eaten by some herbivorous animal, its dung in turn produces more Fungi, which in due course diffuse their spores, and thus the continued production of the Fungus is secured.

The following indirect evidence of the method of spore diffusion by herbivorous animals supports the previous statement. An analysis of the Fungi occurring on dung as given by Saccardo (34) gives the following figures:-On dung of herbivora, 708 species; on carnivora, 45 species; on reptilia, 4 species. Moreover, when the dung of a herbivorous animal is cut into pieces it is found that the cut surfaces yield a crop of Fungi quite equal in number to those produced on the original external surface. The only means of accounting for the growth of Fungi in the position thus described is on the supposition that the spores were swallowed along with the food.

We succeeded in germinating the spores of Ascobolus perplexans and a form of $A$. glaber with dull white apothecia ( $A$. albidus, Crouan) under the following conditions. One sowing was made in a hanging-drop of tap-water, another in a drop of decoction of dung, average temperature $80^{\circ} \mathrm{F}$. After twenty hours nearly all the spores showed vigorous germ-tubes, frequently proceeding from both ends of the 
spore. These germ-tubes at the end of two days had grown to strong branched long hyphae (Fig. 56). The exospore showed a tendency to break up in strips, as is figured by Janczewski (I8) for the germinating spore of Ascob. furfuraceus. In a control experiment with spores of the same form of $A$. glaber at a temperature of about $60^{\circ} \mathrm{F}$. not a single spore had germinated at the end of twenty hours, although subsequently slight germination occurred in many of the spores. As illustrative of the readiness with which the spores of this white form of $A$. glaber germinate, the following fact may be mentioned. Some rabbit-dung, bearing a rich crop of the above Ascobolus, was kept in a tin box. As the asci became ripe the spores were thrown on to the side of the box, where they germinated, and formed a mycelium which eventually produced apothecia. In a second set of experiments, with spores of $A$. perplexans in a hanging-drop of dung decoction at $80^{\circ} \mathrm{F}$., germination was vigorous; but under the same conditions as above, except at $60^{\circ} \mathrm{F}$, no trace of germination occurred. In a hanging-drop of dung decoction with addition of one per cent. of pepsin, temperature $85^{\circ} \mathrm{F}$., germination was very vigorous. In a second culture similar to the last in constituents, but at $65^{\circ} \mathrm{F}$, there was a mere trace of germination. As a set-off against the above our failures to induce germination of the spores of other species of Ascobolus and those of other dung Fungi were numerous, and the only point that appeared in the series of experiments was that the higher the temperature the greater the success in securing germination. This is what would be expected if it is an advantage that spores should pass through the alimentary canal of an animal, although we are inclined for the following reasons to look upon this factor as acquired.

The spores of certain species of Ascobolus that do not grow on dung, but on wood, decaying vegetable matter, or on the ground, germinate readily under artificial conditions, as shown by Boudier (4), whereas, as already stated, the spores of dungborne species as a rule do not germinate at all under similar conditions; nevertheless these highly specialized dung species 
sometimes revert more or less to the habits of the more primitive species yet growing on the ground, thus betraying their origin.

A quantity of dung bearing a rich growth of Ascobolus glaber was kept shut up in a tin box. The mature spores of the Fungus had been ejected and adhered to the lid and sides of the box, where they germinated and produced in due course a plentiful crop of ascophores, which were somewhat paler in colour than the typical form from which they originated: furthermore, the mucilage, which is abundant and of a pale brown colour in the typical form, was very scanty and colourless. Spores obtained from the typical Fungus growing on dung could not be induced to germinate, whereas the spores of the retrogressive form grown on the lid of the box germinated in a hanging-drop of dung decoction at $80^{\circ} \mathrm{F}$., but would not germinate at a lower temperature. Spores of the Fungus growing on the box lid were received on the lid of a Petri dish and in turn produced ascophores, growing in a decoction of plum-jam in gelatine. The spores of these Fungi, representing the second generation removed from the typical form, germinated readily in water at a temperature of $60^{\circ} \mathrm{F}$. The spores of this last generation were passed through the intestinal canal of a guinea-pig, and it was found that no germination had taken place; the spores also refused to germinate afterwards in a decoction of dung at a high temperature.

Eurotium insigne, originally discovered on dung by Winter in Germany, has been met with in great abundance on kangaroo-, horse- and fowl-dung at Kew. Its very large, globose, spinulose spores germinated vigorously in a decoction of dung, soon forming a wefted mycelium which on the fifth day produced the conidial condition of the Fungusa member of the form-genus Gliocladium - and on the eleventh day the young ascigerous condition appeared, reaching maturity in five more days.

Thelebolus stercoreus is of special interest on account of the important position assigned to it by Brefeld in his classification of Fungi. In Brefeld's scheme Thelebolus is placed in the 
class Hemiasci, of which it alone constitutes the division Carpohemiasci, and from it Brefeld considers that the whole of the Carpoasci-Discomycetes and Pyrenomycetes-are derived. His principal reasons for so doing are based on the variability shown in the size of the organ containing the spores-called an 'ascus-like sporangium' by Brefeld-as also in the number of the contained spores. These characters, however, are not more pronounced in Thelebolus than in Ryparobius, which Brefeld admits as a true Discomycete; in fact, in many genera having polysporous asci both in the Discomycetes and Pyrenomycetes the variability in the size of the ascus and in the number of the contained spores is as great as in Thelebolus: Ryparobius, Comesia, Tromera, Fracchiaea, and Coronophora are examples of such genera (cf. Figs. 46, 47).

A distinction of primary importance overlooked by Brefeld is found in the fact that a sporangium is multinucleate from the first, whereas an ascus is at first uninucleate. The spore-containing organ in Thelebolus is at first uninucleate. Further, at maturity the spores are ejected in a mass through a definite opening at the apex, exactly as is the case with the asci of some species of Ryparobius; whereas in the Zygomycetes the spores escape through the irregularly ruptured wall of the sporangium, as in Mucor, or the sporangium is shot off with its contained spores, as in Pilobolus. For the reasons given above we consider the spore-containing organ in Thelebolus to be a typical ascus, and shall speak of it under that name in future.

Brefeld considers that the parenchymatous wall completely surrounding the ascus in Thelebolus is homologous with the weft of vegetative hyphae at the base of the sporangiophore in Mortierella Rostafinskii, and that the long stem-like sporangiophore in the last-named species is represented in a much reduced condition as a single large cell at the base of the ascus in Thelebolus. Respecting the covering of the ascus in Thelebolus, it may be said that morphologically it agrees in every detail with the protective portion known as the ascophore in Ryparobius; it also agrees with the undifferen- 
tiated hyphae present in Mortierella Rostafinskii in originating at a point situated below the specialized reproductive portion of the Fungus - the point of origin common to protective structures in all Fungi. As to the homology of the single large cell, described and figured by Brefeld (5), at the base of the ascus in Thelebolus with the sporangiophore in Mortievella, we may state that an examination of serial microtome sections of Thelebolus does not support this view. The sections show that there exists, not a single cell as stated by Brefeld, but a group or row of large cells representing the ascogonium of the Pezizeae. Owing to the exceedingly minute size of the young ascophore, orientation for the purpose of sectioning is practically impossible. Our sections, although not enabling us to figure the organ in question in detail, prove the existence of some multicellular structure resembling an ascogonium.

Brefeld states that only one ascus is present in an ascophore, and that when two or more asci appear to be present this is due to the growing together of contiguous originally distinct ascophores. In many ascophores of Thelebolus only one ascus is present; serial microtome sections, further, show that contiguous ascophores may adhere to each other; other sections also show that from one to four asci may be present in the same ascophore. In some species of Ryparobius the asci are constantly very few in number, and the structure of the ascophore in such cases is identical with the ascophores of Thelebolus containing several asci. It may be pointed out, also, that in this matter of the variability of the number of asci Thelebolus resembles the genus Sphaerotheca (Erysiphaceae), where as a rule only a single ascus is found in each perithecium, but where in some instances two or three asci occur. In such cases in both Thelebolus and Sphaerotheca the asci are much smaller than the normal solitary ascus.

In conclusion, we fail to detect any evidence of affinity with the Zygomycetes, but on the other hand consider Thelebolus as very closely allied, if even distinct as a genus, from Ryparobius. In this view we are supported by Heimerl (I 7 ), Schroeter (35), and Rehm (3I). 


\section{DistRIBUTION.}

Coprophilous Fungi are somewhat numerous ; Saccardo (34) enumerates 757 species included in 187 genera. Of these, many, so far as is known, occur only on dung; others again, especially those belonging to the Hyphomycetes, are not so strictly confined to dung but may also occur on decaying vegetable matter. Too little is known as yet of the dungflora of many countries to admit of any comparison being made as to relative numbers in different regions or as to the range of individual species, nevertheless records from such localities as Algeria, S. \& E. Africa, Martinique, Ceylon, Borneo, Australia, Tasmania, Tonkin, Malacca, Spitzbergen, United States, Canada, Cuba, Cayenne, Argentina, and Patagonia, show that coprophilous Fungi are widely distributed. Rostrup (33) records no less than seven species of Sporormia, besides species of Saccobolus, Ascophamus, and Raparobius from Greenland. As already stated, the great majority of coprophilous Fungi occur on the dung of herbivorous animals, hence their general distribution will be influenced by the relative number of such animals in a given region.

In addition to the examination of a large quantity of dung of various native and domestic animals from different localities in Britain, we have been enabled, through the kindness of Mr. C. Bartlett, Superintendent of the Zoological Gardens, Regent's Park, to examine the dung of a number of exotic animals, and we find that as a rule the various species of Fungi are not confined to one specific habitat, e.g., certain species, as Gymnoascus Reessii, Eurotium insigne, E. microsporum, Sporormia longipes, and others grow indiscriminately on the dung of any herbivorous animal, and often appear as a successive wave on isolated portions of different kinds of dung. Many different Fungi not unfrequently flourish on the same substratum; seventy-two species have been recorded as growing on rabbit-dung.

When quite fresh dung is placed under a bell-jar the 
sequence of development is as follows: first, Phycomycetes, usually heralded in by Pilaira and Pilobolus, followed by species of Mucor, accompanied by their parasites Chaetocladium, Thamnidium, Piptocephalis, Syncephalis, \&c. ; next appear various members of the Hyphomycetes, probably in many instances representing the conidial condition of the ascigerous Fungi which are usually the last in the sequence to appear.

We have found that dung can be kept under observation for several months if placed in a shallow vessel on a layer of blotting-paper kept constantly moist, and covered with a bell-jar; a small quantity of naphthaline serves to check the ravages of various mites, eelworms, \&c.

\section{Systematic.}

We give below an account of the species which appeared on dung under observation during the six months Oct.March. Only those Fungi belonging to the Ascomycetes are enumerated here, the Phycomycetes and Hyphomycetes being reserved for a future paper. Summarizing the results from a systematic standpoint, we may note the occurrence of two new genera, Pleuroascus ( $P$. Nicholsoni), belonging to the Perisporiaceae, and Spumatoria (S. longicollis) to the Sphaeriaceae. New species of the following genera have appeared: Endomyces coprophilus, Eurotium microsporum, Magnusia Bartlettii, Sordaria globosa, Sporormia longipes, Microascus variabilis, $M$. nidicola, and Melanospora discospora. The following species are new to the British Flora: Myxotrichum uncinatum, Thelebolus stercoreus, Ryparobius ascophanoides, Eurotium insigne, Sordaria anserina, S. minima, S. hirta, S. setosa, S. curvicolla, S. pleiospora, S. macrospora, S. neglecta, S. Winteri, S. fimiseda var. appendiculata, Delitschia moravica, D. insignis, Sporormia ovina, S. pulchella, S. fimetaria, Sphaeroderma fimbriatum and S. Hulseboschii. The genus Bovilla Sacc., founded on the single (British) species $B$. Caproni, proves to be nothing more than the immature condition of Sordaria coprophila. 
A fact worthy of note is the occurrence on the dung of exotic animals from the Zoological Gardens, London, of many British species common on the dung of our native and domestic animals. As instances of this may be mentioned the occurrence in abundance of Ascophamus equinus on the dung of Elephant and Mexican Deer; Ascobolus immersus on the dung of Grys-bok, Sinaitic Ibex, \&c.; Sordaria fimicola on the dung of Elephant and Kangaroo; S. curvula on the dung of Elephant, Giraffe, and Mexican Deer; Sporormia minima on the dung of Giraffe and Dorcas Goat.

It is obvious therefore that, in many cases at least, no character of specific value can be attached to the occurrence of a species on the dung of any particular animal. It may be remarked, also, that in the Sordarieae the superficial or immersed position of the perithecium is to a large extent determined by the hard or soft texture of the dung on which it is growing.

\section{AsCOMYCETES.}

Gymnoascaceae. Endomyces coprophilus, sp. nov. (Fig. 35).

Hyphis arachnoideis irregulariter ramosis crebro septatis albis $4^{-6 \mu}$ crassis, ascis lateralibus brevissime stipitatis piriformibus vel globulosis 4-8-sporis $20-30 \times 18-25 \mu$, sporis ellipticis hyalinis $5-6 \times 3-3.5 \mu$.

Hab.-In fimo equino, Kew, 1894 and Oct. 1900.

On account of the scattered asci the present Fungus is for the time being placed in the genus Endomyces, although it shows little relationship with any of the described species of this genus. In the present plant the creeping mycelium is very delicate and slender, and never becomes concentrated to form a patch visible even under a strong lens,--hence the species is met with only by chance, and intermixed with other Fungi. The Fig. 45, p. I 2, in Mass. Brit. Fung. Fl., by mistake referred to Gymnoascus Reessii, represents the present species.

Arachniotus ruber (van Tiegh.), Schroet. in Cohn's Krypt.-Fl. Schles., Bd. iii, Hälfte 2, 2 I I (1893).

Gymnoascus ruber, van Tiegh. in Bull. Soc. Bot. France, xxiv, I 59 (1877); Sacc. Syll. Fung. viii, 823 (1889); Mass. Brit. Fung. Fl. iv, $19(1895)$.

Hab.-On the dung of Burrhel Wild Sheep (Ovis burrhel), and not uncommon on dog's dung, Kew, Feb.-Mar. I89 I. 
Gymnoascus Reessii, Baran. in Bot. Zeit., xxx, 158 , Taf. III, A (I 872 ); Sacc. Syll. Fung. viii, 823 (I889); Mass. Brit. Fung. Fl. iv, I 9 (excluding Fig. 45, p. I2) (1895).

Hab.-On the dung of Red Deer (Cervus elaphus), Sinaitic Ibex (Capra sinaitica), Roe (Capreolus capraca), Giraffe (Camelopardalis giraffa), Kangaroo (Macropus giganteus) and Rabbit, Kew, Nov.-Mar. I 901 .

Myxotrichum uncinatum (Eidam), Schroet. (Figs. 30-32).

Gymnoascus uncinatus, Eidam, in Cohn's Beitr., Bd. iii, 293 (I880); Wint. in Rabenh. Krypt.-Fl. Deutschl., Bd. i, Abth. 2, I6 (I887); Sacc. Syll. Fung. viii, 824 (I889).

Myxotrichum uncinatum (Eidam), Schroet. in Cohn's Krypt.-Fl. Schles., Bd. iii, Hälfte 2, 2 I 2 (1893).

Tufts rounded, gregarious, about $\frac{3}{4} \mathrm{~mm}$. across, at first sulphuryellow, then becoming dark yellow, and finally reddish, hyphae interwoven, much branched, usually at right angles, septate, towards the interior colourless and ascigerous, at the periphery anastomosing, reddish brown, with numerous long $\left(120-200 \times 5^{-6} \mu\right)$ orange or reddish-orange $\mathbf{I}$-septate or aseptate branches, which at maturity are uncinate at the tip ; asci very numerous, subglobose, $8-9 \mu$ in diameter, borne laterally in dense clusters on colourless hyphae towards the centre of the tuft, wall very evanescent, 8-spored; spores minute laterally compressed, in front view subglobose, $2 \cdot 5-4 \mu$ in diam., in side view ellipsoidal, yellowish, minutely asperous.

Hab.-On Rabbit-dung, Kew, Dec. I900; on dung of Patagonian Cavy (Dolichotis patachonica), Kew, Feb. I 901 .

(Distrib.-Germany, on dung of Mouse, Sparrow, and 'carnivorous animals.')

Each tuft is more or less globular in shape, and is composed of a mass of interwoven hyphae. These hyphae are coloured at the periphery, and frequently anastomose, forming a network-like structure, which bears numerous long uncinate branches or appendages; towards the interior of the ball-like mass the hyphae are colourless and much more delicate, and give origin to an immense number of minute asci. The wall of the ascus is more or less mucilaginous and very evanescent, so that the free spores are found in a dense mass towards the interior of each tuft. Frequently however the spores, after the deliquescence of the ascus-membrane, are held together by mucilage for some time in groups of eight. The spores, under a magnification of 
670 diam, are seen to be distinctly rough with minute scattered points.

The two examples recorded above differ slightly from one another. In the specimens on Rabbit-dung the appendages are slightly narrower, and the spores smaller, measuring (seen from the front) $2 \cdot 5^{-3} \mu$ in diam. ; in the specimens on the dung of Patagonian Cavy the appendages are a little stouter, and the spores larger, although somewhat variable in size, measuring $3-4 \mu$. In both examples the spores are minutely asperous, and the plants indistinguishable in general habit.

Ascobolaceae. Thelebolus stercoreus, Zukal (Figs. 4I-44, 66).

T. stercoreus, Zukal, in Denkschr. d. Math.-Nat. Klasse, Kais. Acad. d. Wissensch. Wien, li, Abth. 2, $2 \mathbf{I}$, Taf. I (1886); Heimerl, in I 5 . Jahresber. d. k. k. Ober-Realsch., Bezirk Sechsh., Wien, 28 (I889); Brefeld, Unters. a. d. Gesammtgeb. d. Myk., ix, I I 3, Taf. III, A (I89 I); Sacc. Syll. Fung. x, 34 (1892); Schroet, in Cohn's Krypt.-Fl. Schles., iii, pt. I, 5I (I 893); Rehm in Rabenh. Krypt.-Fl. Deutschl., Bd. I, Abth. 3, 1106 (1 896 ).

Ryparobius monoascus, Mouton, in Bull. Soc. Roy. Bot. Belg., xxv, pt. I, I 4 I (I 886); Sacc. Syll. Fung. viii, 545 (1889).

Thelebolus nanus, Heimerl, l. c., 30, Taf. I, f. 2 (1889); Sacc. Syll. Fung. x, 34 (1892); Rehm, l. c., I Iо7 (1896).

Apothecia scattered or subgregarious, very variable in size, I35$240 \mu$ in diam., at first closed, globose to ovoid, pallid, becoming dull brownish, glabrous, semi-immersed, wall parenchymatous, very delicate and thin, composed of irregularly shaped polygonal cells $6-14 \mu$ wide, apothecia at length ruptured at the apex by the protruding ascus; ascus solitary, or $2-3$, rarely as many as 5 , ovate-oblong to broadly ovate, variable in size, $120-230 \times 80-170 \mu$, polysporous ; spores $5-7 \times 3-3.5$, oblong, rounded at each end, hyaline, smooth, ejected in a mucilaginous mass to some distance, paraphyses very delicate, hyaline, filiform, sometimes branched, closely surrounding the ascus, soon disappearing.

Hab.-Abundant on Rabbit-dung, Kew and Reigate, England, Nov. I 900 and Mar. I 901 ; on Horse-dung, Kew, Nov. I 900.

(Distrib.-Austria and Belgium; on dung of Hare, Rabbit, Goat, Roe- and Red-Deer.)

The question of the affinity of this interesting Fungus has already 


\section{Coprophilous Fungi.}

been discussed at pp. 319-32I, and it may simply be remarked here that structurally it is to be considered as a Ryparobius containing as a rule only a single very large ascus, but sometimes varying with $2-3$, or even 5 asci. Zukal (1.c.) identified the present species as the Thelebolus stercoreus of Tode (Fungi Mecklenb. select., fasc. I, 4I (I 790)), and this determination has been followed by other authors. A comparison, however, of the characters given by Tode (l.c.) with those of the present plant quite precludes, in our opinion, the supposition that the two plants are identical; e.g. Tode specially characterizes his species as being of a bright yellow colour, the words 'croceus' and 'aureus' being used. Saccardo (Syll. Fung. $\mathrm{x}, 34$ ), adopting the name Thelebolus stercoreus, Tode, for Zukal's plant, places the genus among the Ascomycetes; it is to be noted, however, that Thelebolus terrestris, Alb. and Schw., is a true Gasteromycete.

$T$. nanus was separated from $T$. stercoreus by Heimerl on account of its smaller size, but in examining a large series of growing $T$. stercoreus it becomes clearly evident that $T$. nanus is nothing more than a small form, as a complete series of intermediates can be found growing together. $T$. namus has already been recorded as British by Smith (36).

Associated with normal specimens of $T$. stercoreus (on rabbit-dung, Kew) we met with a Fungus quite similar to that described as Ascozonus oligoascus by Heimerl ( 17 ), except that in our plant we were not able to observe the 'elongate-clavate' yellow hairs which, according to Heimerl, crown the young apothecia. Our Fungus, which is represented at Fig. 45 (cf. Heimerl, l. c., Fig. r, a), appeared to be nothing more than the form of $T$. stercoreus containing 2-3 asci.

Ryparobius ascophanoides, Sacc. (Figs. 33-34).

Ascophanus ryparobioides, Heimerl, Oesterr. Ascob., 22, f. xi (1889).

Ryparobius ascophanoides, Sacc. Syll. Fung. $\mathrm{x}, 33$ (1892); Rehm, in Rabenh. Krypt.-Fl. Deutschl., Bd. i, Abth. 3, I Iог (I896).

Scattered, very minute, $\frac{1}{4}-\frac{1}{3} \mathrm{~mm}$., white, almost hyaline when moist, sessile on a broad base, disk slightly concave, glabrous ; asci few, $6-8$, broadly clavate, $160 \times 60 \mu, 3^{2}$-spored; spores elliptic, ends obtuse, smooth, I 5-16 $68-9 \mu$; paraphyses filiform, apex not thickened, septate, about $2 \mu$ thick.

Hab.-On rabbit-dung, Kew. (Distrib.-Austria, on Deer's dung.)

Allied to $R$. sexdecimsporus (Cr.), Boud., differing in the broadly clavate asci, containing thirty-two spores. The above measurements 
of asci and spores are taken from the British specimens. Heimerl (l. c.) gives the size of asci and spores as follows: asci, 120-I74 $\times 5^{0-73 \mu}$; spores, $14.5-17.5 \times 7-8.5 \mu$. In the British specimens each ascus contained thirty-two spores; Heimerl states that this is the usual number for the present species, although he has observed cases of the occurrence of twenty-nine and about forty-five spores in an ascus. In $A$. sexdecimsporus the normal number of spores in each ascus is sixteen ; it may be worth recording here, however, that in one instance we observed eighteen fully-formed spores to be present.

Ascophanus microsporus (Berk. and Br.), Phill.; Mass. Brit. Fung. Fl. iv, 773 (1895).

Hab.-On the dung of Argali Sheep (Ovis ammon), Kew, Nov. 1900.

A. equinus, Mass. Brit. Fung. Fl. iv, I79 (I895); Boud., Mém. Ascob. 254, Pl. 1 2, xlii-xliv (1869).

Hab.-On the dung of Mexican Deer (Cariacus mexicanus) and Elephant (Elephas africanus), Kew, Dec. I900.

A. ochraceus (Cr.), Boud., Mém. Ascob. 247, Pl. II, xxxiv (1869); Mass. Brit. Fung. Fl. iv, 176 (1 895 ).

Hab.-On the dung of Burrhel Wild Sheep (Ovis burrhel), Mar. I $90 \mathbf{I}$.

Ascobolus perplexans, sp. nov. (Figs. 52-55).

Apotheciis sparsis luteo-virentibus extus minutissime furfuraceis mox glabris piriformibus, disco initio concavo demum plano vel subconvexo, acute marginatis $0.5^{-1} \mathrm{~mm}$. latis; ascis cylindraceis basi attenuatis octosporis $190-2 \mathrm{IO} \times \mathrm{I} 6-20 \mu$; sporis oblongo-ovatis monostichis $18-19 \times 9-10 \mu$, episporio longitudinaliter rimuloso et parce reticulato demum verruculoso violaceo; paraphysibus filiformibus, interdum ramosis, sursum incrassatis septatis saepe nodulosis muco flavovirente obvolutis.

Hab.-In fimo Raphiceri melanotidis (Grys-bok), Elephantis africani (Elephant), Macropodis gigantei (Kangaroo), Cervi elaphi (Red Deer), Ovis vignei (Ural Wild Sheep), Kew, Nov.-Feb. I901; in fimo equino, S. Kensington, Mar. I 90 I.

A very beautiful species, perhaps most nearly allied to $A$. glaber, Pers. The epispore is at first simply longitudinally cracked, but at a later stage it becomes broken up in an areolate manner, the small portions of epispore resembling minute warts under a magnification of 400 diam.

A. vinosus, Berk., Boud., Mém. Ascob. 22 I, Pl. 6, xi. (1869), Mass. Brit. Fung. Fl. iv, I 59 (I 895 ). 


\section{Coprophilous Fungi.}

Hab.-On Goose-dung, Kew, Dec. I900.

A. immersus, Pers.; Boud., Mém. Ascob. 226, Pl. 8, xvii (1869), Mass. Brit. Fung. Fl. iv, I 68 (I895).

Hab.-On dung of Grys-bok (Raphicerus melanotis), Sinaitic Ibex (Capra sinaitica), Red Deer (Cervus elaphus), and Ural Wild Sheep (Ovis vignei), Kew, Nov.-Dec. 1900.

Saccobolus quadrisporus, sp. nov. (Figs. 48-5I).

Apotheciis $\frac{1}{2}-\frac{2}{3} \mathrm{~mm}$. diam., primo plus minus convexulis diaphanis aquoso-violaceis demum planis opacis atro-violaceis vel nigrescentibus, maturitate disco ob ascos exsilientes brunneo-punctato, ascis subcylindraceis sursum truncatis, deorsum breviter stipitatis saepe curvatis 95-I IO X I 8-20 $\mu$, jodo caerulescentibus quadrisporis; paraphysibus simplicibus vel furcatis filiformibus apice clavulatis septatis; glomerulis sporidiorum ellipticis $40-45 \times 15^{-1} 6 \mu$, sacculo communi hyalino inclusis, sporidiis in una vel duabus seriebus ordinatis atro-violaceis, $20 \times 8$ - $10 \mu$, praesertim ad margines verrucis minutis praeditis.

Hab.-In fimo anserino, Royal Gardens, Kew, Nov. 1900.

A congeneribus ascis quadrisporis distinguenda.

The apothecia of the present species are at first of a clear watery violet colour, but gradually become with age less translucent and darker in colour. At maturity the disk is studded with the apices of the protruding asci, and at this stage, if the ascophore is placed in a drop of water, the ripe asci eject their spores, still surrounded by their 'sac,' into the water. The outline of this 'sac,' or mucilaginous covering, round the ejected spores, is almost invisible without staining, but on using methyline blue the mucus becomes clearly visible. A considerable number of ascophores were examined, and in every case the asci were found to be tetrasporous. The spores when separated appear somewhat trigonous in shape; when seen in the clustered position (Fig. 5I) each spore shows a pale line running across it, which is apparently due, not to a crack in the epispore, but to a greater translucency in this part, caused by the shape of the spore. The epispore is broken up into the wart-like bodies only on the free side of each spore. The ascospores are usually arranged in two parallel rows as shown at Fig. $5 \mathrm{I}$; not unfrequently, however, the four spores are found arranged side by side in one row.

S. Kerverni (Cr.), Boud., Mém. Ascob. 229, Pl. 8, xviii (1869); Mass. Brit. Fung. Fl. iv, I 7 I (I895). 
Hab.- On Horse-dung, Reigate, Surrey, Dec. I900; on dung of Mexican Deer (Cariacus mexicanus) and Dorcas Goat (Capra dorcas), Kew, Dec. 1900.

S. depauperatus (Berk, and Br.), Rehm; Mass. Brit. Fung. Fl: iv, I 70 (1895).

Hab.-On dung of Mexican Deer (Cariacus mexicanus), Kew, Feb. I 901 .

S. neglectus, Boud., Mém. Ascob. 23I, Pl. 9, xx (I869); Mass. Brit. Fung. Fl. iv, I 7 I (1895).

Hab.-On dung of Ural Wild Sheep (Ovis vignei), Kew, Feb. I90I.

Pezizaceae. Helotium lacteum (Cke and Phill.), Mass. Brit. Fung. Fl. iv, 269 (I 895 ).

Hab.-On Rabbit-dung, Kew, Dec. I 900.

\section{Perisporiaceae. Pleuroascus, gen. nov.}

Perithecia subiculo intertexto pannoso distincto vel confluente insidentia, atra, astoma, membranaceo-carbonacea, fragilia, contextu parenchymatico, appendicibus pluribus hyalinis arcte spiraliter convolutis instructa ; ascis globosis minutis numerosissimis mox diffluentibus in hyphis ramosis pleurogenis ; sporis minutis fuligineis globosis.

The present genus appears to be distinct among the Phaeosporae of the Perisporiaceae in the dense pannose subiculum and the minute globose laterally-borne asci. The asci are produced in great numbers, and arise in a glomerulate manner on the delicate branched hyphae which fill the perithecium. This latter character suggests affinity with Cephalotheca.

P. Nicholsoni, sp. nov. (Fig. 25 ).

Peritheciis in subiculo pannoso distincto vel confluente primum albo deinde rufescente e hyphis delicatulis ramosis intertextis composito plus minus immersis, dense gregariis, parvis, $130-200 \mu$ diam., atris, fragilibus, contextu parenchymatico e cellulis distinctis $6-10 \mu$ latis composito, appendicibus pluribus e parte perithecii inferiore orientibus hyalinis arcte spiraliter convolutis compressis septatis; ascis numerosissimis minutis globosis $8 \mu$ diam., mox diffluentibus, in hyphis ramosis dense glomerulatis; sporis octono-conglobatis, globosis, minutis, circ. $3 \mu$ diam., fuligineis.

Hab.-In fimo Caviae cobayae (Guinea Pig), Kew, England, Jan. I 9 o I (coll. Geo. Nicholson).

The dense pannose subiculum, in which the perithecia are at first 
more or less completely immersed, is when young of a pure white colour, but finally becomes at the time of the maturity of the perithecia of a dull rusty colour. It may in advanced age disappear altogether, leaving the perithecia exposed, but held together in masses by the interwoven elastic spiral appendages. The appendages remain permanently hyaline, and closely spirally wound. They are compressed and ribbon-like in structure and arise from the equatorial and basal cells of the external wall of the perithecium. The appendages when drawn out are seen to be very long, many times exceeding the diameter of the perithecium. The spores remain for some time hyaline, but become finally distinctly fuliginous.

Eurotium insigne, Wint. (Figs. 29, 39-40).

E. insigne, Wint., in Rabenh. Fung. eur., nr. 1732 (1874); Wint. in Rabenh. Krypt.-Fl. Deutschl., Bd. i, Abth. 2, 6I (1887).

Penicillium insigne (Wint.), Schroet., in Cohn's Krypt.-Fl. Schles., Bd. iii, 220 (1893).

The conidial form of this species is Gliocladium penicilloides, Corda, Icon. Fung. iv. 3 I, Pl. VII, f. 92 ( 1840$)$; Grove, in Journ. of Bot. xxiii, 165 , tab. 256 , f. 9 (1885); Sacc. Syll. Fung. iv, 85 (1886); Massee, Brit. Fung. Fl. iii, 293 (1893); Matruch., in Rev. génér. d. Bot. vii, 322, Pl. XVI, ff. I-I0 (1895).

G. macropodinum, March., in Bull. Soc. Roy. Bot. Belg. xxxiv, pt. I, I 35, Pl. I, f. 6, a, b (I895); Sacc. Syll. Fung. xiv, I048 (I 900).

Mycelium inconspicuous, perithecia large, $\frac{1}{2}-\mathbf{I ~} \mathrm{mm}$. in diam., superficial, globose, glabrous, when young clear white, then pallid, becoming yellowish, and finally rusty-brown, thin-walled, membranaceous, wall composed of large polygonal or irregularly-shaped cells $15^{-20} \mu$ wide ; asci numerous, subglobose or globose-pyriform, with a short stalk, $45^{-6}-6 \times 3^{8-45 \mu} \mu$, very evanescent, 8 -spored; spores large, globose, I 7-20 $\mu$ diam., covered all over with short acute spines, at first colourless, becoming distinctly grey.

Hab.-On dung of Kangaroo (Macropus giganteus), Kew, Jan. I901 ; on dung of Burrhel Wild Sheep (Ovis burrhel), Mar. 1901 ; on dung of Fowls, Kew, Jan. I90I ; on Horse-dung (originally from Epping Forest), Kew, Feb. Igor, (Distrib.-(of ascigerous form), Germany and France ; on dung of Goose and Dog.)

A remarkable and very distinct species in its large size and strongly spinous spores, which finally become distinctly grey in colour. Winter, in first describing the Eurotium in Rab. Fung. Eur., remarked that 


\section{Massee and Salmon.-Researches on}

Gliocladium penicilloides, Corda, which was observed by him closely associated with it, probably represented the conidial stage. In 1895 , Matruchot (l.c.) in cultivating Gliocladium penicilloides obtained ascigerous perithecia, which, from the description given, were clearly those of Eurotium insigne, Wint. Matruchot, sowing the ascospores obtained in this way, found that they produced a mycelium which gave rise to the conidiophores of the Gliocladium. In our examples, recorded above, on the dung of Fowls, Kangaroo, and Horse, the Eurotium was in each case preceded by the Gliocladium, and we were able to observe clearly the organic continuity of the two forms, the same mycelium which produced conidiophores bearing the young perithecia. Culture experiments were also made, with the result of confirming fully Matruchot's observations. Ascospores were sown on sterilized films of cork floating on a decoction of dung. These ascospores germinated readily, producing a mycelium which at the end of five days gave rise to typical conidiophores of Gliocladium penicilloides. After eleven days the same mycelium produced perithecia (containing young asci) of Eurotium insigne.

The Gliocladium, recorded as a new species under the name of $G$. macropodinum, by Marchal, on the dung of Kangaroo, is evidently not distinct from $G$. penicilloides, the distinguishing character relied upon, viz. the greater length of the conidia- ' $9-$ I I $\mu$ long' instead of ' $6 \mu$ long,' being quite insufficient. In our specimens, on the dung of Kangaroo, \&c., the conidia varied from 7-I $2 \mu$ in length ; Matruchot, also, expressly states that the size of the conidia is extremely variable in the species of Gliocladium, and gives $5-10 \mu$ as the length of the conidia in $G$. penicilloides.

Grove (l. c.) remarks that Gliocladium differs from Penicillium in the spores being produced singly, not in chains; this statement, however, is erroneous, as in both genera the spores are originally produced in chains, but in Gliocladium, as Matruchot points out, the spores soon lose this arrangement, and become irregularly massed in the mucilaginous head. Grove, also, referred doubtfully the Penicillium-like fungus represented by Cooke in Plowright's Monograph of the British Hypomyces (Grevill. xi, 49, Pl. I 56 ) as occurring associated with Hypomyces aureo-nitens, Tul., to Gliocladium penicilloides, and for this reason the statement occurs in Mass. Brit. Fung. Fl. iii, 294, that $G$. penicilloides ' is considered to be the conidial stage of Hypomyces aureo-nitens.' It is quite clear, however, that the Fungus 
occurring with the Hypomyces was not Gliocladium, as the characteristic mucilaginous covering of the heads was absent.

On account of the characters shown in its conidial stage, and on account of the dark-coloured ascospores, it seems doubtful if the present Fungus should remain in the genus Eurotium; it should perhaps, as Winter and Matruchot think, be made the type of a new genus.

F. microsporum, sp. nov. (Fig. 28).

Peritheciis parvulis sparsis circ. I $30 \mu$ diam. globosis primo flavovirentibus dein citrinis superficialibus contextu parenchymatico e cellulis tenuibus $5^{-8} \mu$ latis composito; ascis sphaeroideis vel subsphaeroideis $7-8 \mu$ diam., citissime diffluentibus, octosporis; sporis minutissimis sphaeroideo-biconvexis $2 \mu$ diam. laevibus chlorinis.

Hab.--In fimo Capreoli capraeae (Roe), Haplocerotis montani (Rocky Mountain Goat), Caprae dorcadis (Dorcas Goat), Caprae sinaiticae (Sinaitic Ibex), Ovis vignei (Ural Wild Sheep), Caviae cobayae (Guinea Pig), Kew, Jan.-Feb. I $90 \mathbf{r}$.

The present species is remarkable for the small size of the ascospores, and also for the manner in which they become exposed at maturity. The wall of the perithecium, which is at first sage-green in colour and then yellowish, becomes dry and very brittle when the perithecia are quite ripe, and completely falls away, exposing the chrome-yellow mass of spores. The perithecia occur singly, dotted at intervals on the dung, and when crushed under the microscope are seen to be filled with innumerable minute free ascospores. Except in the early stages of the development of the perithecium it is difficult to find any trace of asci, as the walls of the latter deliquesce almost immediately. The spores viewed from the front are roundish in outline; from the side, biconvex.

Magnusia Bartlettii, sp. nov. (Fig. 26).

Peritheciis sparsis superficialibus globosis nigris $\frac{1}{4}-\frac{1}{2} \mathrm{~mm}$. diam., contextu parenchymatico e cellulis minutis polygonis distinctis circ. $4 \mu$ latis composito, apice coma pilorum ornatis, pilis 8-I 2 rigidis simplicibus plus minus divergentibus atro-fuscis laevibus sparse septatis apice interdum flexuosis basin versus circ. $6 \mu$ latis perithecii diametro duplo vel triplo longioribus, caeterum glabris; ascis numerosis globosis ( $18-20 \mu$ diam.) vel oblongo-piriformibus $(20-25 \times 14-$ I $7 \mu$ ) 6-8-sporis, cito diffluentibus; sporis ellipticis utrinque acutis $8-1 \circ \times 5 \mu$, primum hyalinis demum distincte dilute fuligineis. 
Hab.-In fimo Capreoli capraeae (Roe), Caviae cobayae (Guinea Pig), Ovis burrhel (Burrhel Wild Sheep), Ovis vignei (Ural Wild Sheep), Kew, Jan.-Feb. r 90 I.

The above species appears to be distinct from $M$. nitida, Sacc.the only other species in the genus-in the simple, not uncinate, appendages, which are narrower and more flexuose. It appeared first on the dung of an albino Roe, sent from the Zoological Gardens by Mr. Bartlett.

Sphaeriaceae. Chaetomium elatum, Kze; Cooke, Handb. Brit. Fung. $65_{2}^{2}$ (187I); Zopf, Entw. Ascomycet. (Chaetomium), 83 (I88I). C. comatum (Tode), Fr., Sacc. Syll. Fung. i, 22 I (1882).

Hab.-On dung of Red Deer (Cervus elaphus), Kew, Dec. I 900.

C. murorum, Corda ; Cooke, Handb. Brit. Fung. 653 (187 I); Zopf, Entw. Ascomycet. (Chaetomium), 80, Taf. VI, ff. I 3-20 (188I); Sacc. Syll. Fung. i, 223 (1882).

Hab.-On dung of Red Deer (Cervus elaphus), Roe (Capreolus capraea), Dorcas Goat (Capra dorcas), Sinaitic Ibex (C. sinaitica), Burrhel Wild Sheep (Ovis burrhel), and Ural Wild Sheep (O. vignei), Kew, Jan.-Mar. r 90 I.

Sordaria globosa, sp. nov. (Fig. 2I).

Peritheciis subgregariis primo subimmersis dein plus minus superficialibus globosis circ. $\frac{3}{4} \mathrm{~mm}$. diam. glabris olivaceis, ostiolo papilliformi atro subcarbonaceo, contextu parenchymatico e cellulis tenuibus composito; ascis numerosis cylindraceis deorsum in stipitem longum attenuatis octosporis $300-35^{\circ} \times 35-50 \mu$; sporis ellipticis $35-40 \times$ $20-22 \mu$, basi tantum appendiculo hyalino cylindraceo saepe attenuato persistente recto vel curvulo $25-3 \circ \mu$ longo auctis.

Hab.-In fimo Macropodis gigantei (Kangaroo) et Cervi elaphi (Red Deer), Kew, Feb. I90I.

Peritheciis globosis glabris et sporis majusculis basi tantum caudatis mox dignoscenda species.

The Fungus described above is well marked in the globose perithecia, which are of a rather pale olivaceous colour, with a very dark brown or black papilliform ostiolum, and the large spores, each with a single basal appendage. The latter is a true cell, with a distinct cell-wall.

S. anserina (Rabenh.), Wint. (Fig. 6).

Malinvernia anserina, Rabenh. in Herb. Myc., nr. $5^{26}$. 
Sordaria anserina, Wint., Deutsch. Sordar., 99, Taf. XI, Fig. 20 (1873); Sacc. Syll. Fung. i, 238 (1882); Wint. in Rab. Krypt.-Fl. Deutschi., Bd. i, Abth. 2, I 73 (I887).

Perithecia gregarious, up to $\frac{1}{3} \mathrm{~mm}$. high, semi-immersed, blackishbrówn, rugulose, basal part subglobose narrowed upwards into a long or short curved rather thick bluntly conical neck, which bears a tuft of hairs below the apex on one side, hairs bristle-like long rigid dark brown, each usually composed of a fascicle of slender hyphae, roo250 (rarely $35^{\circ}$ ) $\mu$ long, $3.5 \mu$ wide ; asci cylindrical, attenuated below into a rather long pedicel, about $280 \times 25-30 \mu, 4$-spored; spores uniseriate, ovate to broadly ovate, $36-44 \times 18-22 \mu$, provided at the more or less truncate basal end with a definite hyaline appendage about equalling the spore in length.

Hab.-On Goose-dung, Royal Gardens, Kew, England, Nov. 1900 ; on dung of Giraffe (Camelopardalis giraffa) and Kangaroo (Macropus giganteus), Kew, Dec. I900.

(Distrib.-Germany and N. Italy ; on dung of Goose, Cow, Sheep, Horse, and Rabbit.)

S. anserina is easily distinguished among the Sordariae by its perithecia possessing towards the base of the curved beak, on one side only (the convex side), a conspicuous tuft of bristle-like hairs, and by its 4 -spored asci. Winter records cases where only two spores occurred in the ascus; in such cases the ascus is much shorter than the normal tetrasporous one, while each of the two spores is twice the usual size. The external perithecial wall of $S$. anserina appears frequently to have a rather curious structure, being irregularly marked with peculiar dark-coloured thickened portions on a pale membrane, and so is not truly cellular. The same structure is often found in S. setosa, Wint. The spores when young have appendages at both ends, but at maturity the basal end only, which is more or less truncate, possesses a rather thick appendage about equalling the length of the spore.

S. minima, Sacc. and Speg. (Fig. II).

S. minima, Sacc. and Speg., in Mich. i, 373 (1878); Fung. Ital. t. 6 I 7 (1879).

Hypocopra minima, Sacc. Syll. Fung. i, 244 (1882).

Perithecia more or less superficial, very small, about $100 \times 80 \mu$, broadly ovate, glabrous, perithecial wall membranous, thin, very pale brown or almost colourless, translucent, cells about $5 \mu$ wide; asc few, 
cylindrical, shortly stalked, $45-60 \times 8$-10 $\mu, 8$-spored: spores uniseriate, ovoid, $4.5^{-8 \times 3^{-4} \mu}$.

Hab.-On Rabbit-dung, Royal Gardens, Kew, England, Oct. I 900; on Hare-dung, Kew, Mar. I90I. (Distrib.-N. Italy ; on Cow-dung.)

S. minima has hitherto been known from only a single locality in Italy. The species is at once recognized by the small size of all its parts, and being almost invisible under a simple lens, is probably often passed over. Saccardo and Spegazzini give the size of the spores as $8 \times 4 \mu$, but in our specimens one perithecium contained asci with spores measuring only $4.5 \times 3 \mu$; in other instances, however, the spores measured $6-7 \times 3 \cdot 5-4 \mu$. The wall of the perithecium is so translucent that the asci and coloured spores can be seen within the closed perithecium.

S. hirta, Hans. (Fig. 7).

S. hirta, Hans., in Vidensk. Meddel., I876, p. 336, Pl. VII, ff. I 7-24 (1876-77); Sacc. Syll. Fung. i, $23^{2}$ (I 882 ).

Perithecia rather large, $\mathbf{I}-\mathbf{I} \frac{1}{2} \mathrm{~mm}$. high, basal part subglobose, olivaceous, narrowed upwards into a rather long, blackish, conical neck, which is more or less covered with dark brown or nearly black septate rigid simple hairs; asci long-stalked, clavate-fusoid; spores 8 (rarely 4), ovoid, $40-46 \times 20-22 \mu$, furnished at both ends with a hyaline appendage about equalling the spore in length.

Hab.-On Cow-dung, Kew, England, Nov. 1900. (Distrib.-Denmark, on Cow-dung.)

Hansen (l.c.) remarks that the size of the spores is extremely variable in the present species, and records cases of spores varying between the wide limits of $24-5^{8} \times 13 \cdot 5^{-2} 5 \mu$.

S. setosa, Wint. (Fig. I 3 ).

S. setosa, Wint., Deutsch. Sordar. 97 , Taf. X, f. I 8 (1873); Schroet. in Cohn's Krypt.-Fl. Schles., Bd. iii, Hälfte 2, 288 (1894).

Philocopra setosa, Sacc. Syll. Fung. i, 249 (1882).

Podospora setosa, Wint., in Rabenh. Krypt.-Fl. Deutschl., Bd. i, Abth. 2, I 76 (I 887 ).

Perithecia scattered or subgregarious, $\frac{1}{3}-\frac{1}{2} \mathrm{~mm}$. high, greenish black, often surrounded at the base with spreading pallid hyphae, subimmersed or wholly superficial, subglobose with a short or rather long bluntly conical blackish neck, which is sometimes slightly curved, neck and sometimes the upper part of perithecium more or less covered with long stiff greyish acute mostly aseptate bristles, usually 
about $\mathrm{I}_{5}{ }^{\circ} \mu$ long, but varying in length from $50-300 \mu$, bristles sometimes arranged in tufts; asci about $15,250-300 \times 50-60 \mu$, broadly cylindrical or ventricose, narrowed towards the apex, shortly stalked, wall very thin, soon deliquescing, $\mathbf{2} 28$-spored; paraphyses multiseptate, filiform, about equalling the asci ; spores greenish-black, ellipsoid, I 8-20 $\times$ IO-II $\mu$ (collected into a mass measuring about $250 \times 55 \mu$ ), at first with appendages at both ends, but eventually with a single straight hyaline appendage at the basal end only, usually slightly shorter than the spore.

Hab.-On Rabbit-dung, Kew, England, Jan. I90I ; on dung of Giraffe (Camelopardalis giraffa), Red Deer (Cervus elaphus), Mexican Deer (Cariacus mexicanus), Sinaitic Ibex (Capra sinaitica), Dorcas Goat ( $C$. dorcas), Ural Wild Sheep (Ovis vignei), Kew, Nov. 1900Feb. 190I. (Distrib.-Germany; on dung of Goose and Sheep, also cultivated on Horse- and Cow-dung, and on paper saturated with dung.)

The present species is easily distinguished from most of the Sordariae by its many-spored asci; from $S$. pleiospora, Wint., described below, it differs in its more hairy perithecium, and the more numerous much smaller spores; from $S$. curvicolla, Wint., it is distinguished by its slightly larger spores and by the ascus being narrowed towards the apex (Fig. I3). The spores at a certain stage in their development possess thread-like appendages, often apparently of indefinite length, at each end, but when the spores are mature, or nearly so, only a single appendage, about $3 \mu$ wide and slightly shorter than the spore, is found at the basal end. Winter (Deutsch. Sordar. (1.c.)) figures and fully describes the development of the spores. Zukal (53) states that the stiff bristle-like hairs surrounding the ostiolum first appear towards the end of the period of the ejaculation of the spores.

S. curvicolla, Wint. (Fig. I2).

S. curvicolla, Wint., in Hedwigia, $\mathrm{x}, \mathbf{1 6} \mathbf{1}$ (1871); Wint., Deutsch. Sordar. 98, Taf. X, f. 19 (1877); Speg. in Michel. i, 228 (1878).

Philocopra curvicolla (Wint.), Sacc. Syll. Fung. i, $25 \circ$ (1882).

Podospora curvicolla, Wint., in Rabenh. Krypt.-Fl. Deutschl., Bd. i, Abth. 2, I 76 (1887).

Perithecia scaitered, immersed to the base of the neck, basal part ovate-globose narrowed upwards into a rather long thick obtuse neck, wall parenchymatous, upper part of perithecium, including the neck, 
more or less covered with short hairs; asci ventricose or ovate-saccate, shortly pedicellate, not narrowed upwards but broadly rounded at the apex, about $\mathrm{I} 28$-spored, $270-350 \mu$ long, about $\mathrm{I} 20 \mu$ broad; spores ellipsoid, I $5^{-1} 6 \times 9-10 \mu$, with a hyaline cylindrical basal appendage, slightly shorter than the $\mathrm{s}$ ore.

Hab.-On Rabbit's dung, Kew, England, Feb. rgor. (Distrib.Germany and N. Italy ; on dung of Mouse, Rabbit, and Hare.)

$S$. curvicolla is distinguished from $S$. setosa, Wint., - to which it is closely allied,- - by its smaller spores, and especially by the shape of its ascus, which is broadly rounded at the apex, not narrowed upwards.

A form of the present species, with $I_{50}$ spores in the ascus, is recorded by Griffiths (Bull. Torr. Bot. Club, xxvi, $437, \mathrm{Pl}_{3}{ }_{36}$, ff. I $3^{-1} 5$ (1899) ) from the United States, growing with Sordaria curvula on Salsola kali, var. tragus.

S. pleiospora, Wint. (Fig. I4).

S. pleiospora, Wint., in Hedwigia, x, I6I (I87I); Wint., Deutsch. Sordar., 93, Taf. X, f. I 7 (I 873) ; Schroet. in Cohn's Krypt.-Fl. Schles., Bd. iii, Hälfte 2, 288 (I 894 ).

Philocopra pleiospora, Sacc. Syll. Fung. i, 249 (I882).

Podospora pleiospora, Wint., in Rabenh. Krypt.-Fl. Deutschl., Bd. i, Abth. 2, I 75 (I887).

Perithecia dark brown or blackish, up to I $\mathrm{mm}$. high, scattered, at first subimmersed, but becoming finally wholly superficial, basal part subglobose narrowed upwards into a thick bluntly conical neck, which is nearly glabrous, lower part of perithecium provided with rather long scattered soft flexuous greyish-brown septate hairs, cells of perithecial wall small, $6-7 \mu$ wide; asci broadly cylindrical or ventricose, narrowed towards the apex, about $300 \times 60-80 \mu$, I 6-64spored; spores ovoid, somewhat truncate at one or both ends, $25-30 \times 15-18 \mu$, at first with an appendage at each end, but at maturity losing both appendages.

Hab.-On dung of Giraffe (Camelopardalis giraffa), Kew, Jan. I $90 \mathbf{1}$. (Distrib.-Germany, N. Italy, Poland ; on dung of Horse, Cow, and Hare.)

Easily distinguished from $S$. setosa and $S$. curvicolla by the fewer and larger spores. These three species-S. pleiospora, $S$. setosa, and S. curvicolla -are by some authors placed in a separate genus, Philocopra, founded solely on the polysporous asci. This one character, 
however, cannot be considered sufficient to separate the species from Sordaria, and it seems better, with Schroeter (l. c.), to treat the distinction as having a sectional value only within the genus.

Griffiths (Bull. Torr. Bot. Club, xxvi, $43^{8}$ (1 899)) records a Sordaria under the name of $S$. pleiospora from the United States, but the characters given differ so much in important points from those of the present species that it seems very doubtful if $S$. pleiospora was really found.

The spores are recorded by most authors as varying from $16-64$, and Winter states that the latter is the highest number reached; in our examples, however, asci containing 76 spores were observed.

S. macrospora, Auersw. (Fig. 9).

S. macrospora, Auersw., in Rab. Fung. Eur., nr. 954 ; Niessl. Beitr., p. 3 o, Tab. VI, f. 43 (I 872 ); Wint., Deutsch. Sordar., 79, Taf. VII, f. 4 (I873); Wint. in Rabenh. Krypt.-Fl. Deutschl., Bd. i, Abth. 2, I 65 (1887); Schroet. in Cohn's Krypt.-Fl. Schles., Bd. iii, Hälfte 2, 286 (I 894$)$.

Hypocopra stercoris, Fckl., Symb. Myc. 24 I (I 869).

H. macrospora, Sacc. Syll. Fung. i, 24I (I882).

Perithecia black, gregarious or crowded, glabrous, semi-immersed or entirely superficial, $\frac{1}{3}-\frac{1}{2} \mathrm{~mm}$. in height, basal part subglobose narrowed upwards into a short bluntly conical neck, perithecial wall parenchymatous, cells $10-20 \mu$ wide; asci elongate-cylindrical, $2 \mathrm{I} 0-300 \times 18-30 \mu$, tapering below into an evident stalk, apex rounded, thickened, 8-spored; spores uniseriate, broadly obovate or oblong, rounded at the apical end, and acutely and minutely pointed at the basal end, $24-3 \mathrm{I} \times \mathrm{I}_{5}-\mathrm{I} 8 \mu$, surrounded by a narrow layer of mucilage.

Hab.-On dung of Hare (Lepus europaeus) and Kangaroo (Macropus giganteus). Kew, Dec. I900. (Distrib.-Finland, Germany, Poland, N. Italy, on dung of Hare, Sheep, Mouse, Rabbit, Horse, and Cow.)

S. macrospora is easily recognized by the peculiarly incrassate apex of the ascus and the broad spores minutely pointed at the basal end. The latter character, which has not apparently hitherto been noted, is found also in the spores of the closely related S. fimicola (Rob.), Ces. and De Not., which differs in the smaller, narrower spores, surrounded by a wider layer of mucilage.

On Hare-dung the perithecia are more or less immersed, while on Kangaroo-dung they are entirely superficial.

S. neglecta, Hans. (Fig. I5). 
S. neglecta, Hans., in Vidensk. Meddel., I876, p. 335, Tab. IX, ff. I 2-I 8 (1876-77); Sacc. Syll. Fung. i, 232 (1882).

Perithecia rather large, about I $\mathrm{mm}$. high, semi-immersed, basal part subglobose, narrowed upwards into a short blackish bluntly conical or papilliform neck; asci longly cylindrical or somewhat fusiform, narrowed into a long stalk, rounded at apex, 400-500 $\times 35 \mu$, 8-spored; spores uniseriate, broadly ovoid, 40-50 $\times 25^{-29} \mu$, provided at each end with a permanent hyaline usually curved appendage, about equalling the spore in length.

Hab.-On Cow-dung, Reigate, England, Nov. 1900. (Distrib.Denmark, on Cow- and Horse-dung.)

A fine and apparently uncommon species, distinguished by its large spores with two permanent appendages.

S. Winteri, Karst. (Fig. 5).

S. Winteri, Karst., Myc. Fenn. ii, 25 I (1873); Sacc. Syll. Fung. i, 234 (1882).

S. breviseta, Karst. (nec Fckl.), Myc. Fenn. ii, $5^{2}$ (1 873 ).

Perithecia scattered or gregarious, at first immersed, becoming free, $\frac{1}{3} \mathrm{~mm}$. high, basal part subglobose, olivaceous, narrowed upwards into a short conical blackish neck, which is more or less covered with short, scattered, rigid, acute, septate dark brown hairs; asci cylindrical-clavate, pedicellate, sporiferous part about $150 \times 30-40 \mu$, 8-spored; spores ellipsoid, $23^{-2} 5 \times 15^{-16} \mu$, provided at the basal end with a hyaline appendage slightly shorter than the spore.

Hab.-On Horse-dung, Kew Green, England, Dec. I900. (Distrib.Finland, on dung of Horse, Cow, and Hare.)

S. fimiseda, Ces. et De Not., var. appendiculata (Auersw.) (Fig. I6).

S. appendiculata, Auersw., Niessl. Beitr., p. $3^{8}$, Tab. V, f. 40 (1872); Sacc. Syll. Fung. i, 234 (1882).

S. fimiseda, Ces. et De Not., Wint. in Hedwigia, xiii, 55, f. v (partim) (I874); Wint., Deutsch. Sordar. 89, Taf. IX, f. I3 (partim) (1877).

Podospora fimiseda, var. appendiculata (Auersw.), Wint. in Rabenh. Krypt.-Fl. Deutschl., Bd. i, Abth. 2, I 70 (I887).

Perithecia scattered or gregarious in small clusters, superficial, ovateconical in general outline, basal part ovate-globose narrowed upwards into a short thick usually curved neck, blackish-brown, basal part of perithecium covered with long soft flexuose spreading hairs, which are 
fuliginous, septate, and about $2-3 \mu$ wide, neck, especially at apex, densely covered with similar but shorter and erect hairs, wall of perithecium composed of small cells about $5 \mu$ wide; asci cylindrical, about $220 \times 30-35 \mu$, gradually attenuated into a long stalk, 8-spored ; spores broadly elliptical, $28-30 \times 19-20 \mu$, appendiculate at each end, basal appendage persistent, rather stout, shorter than the spore ( $15-18 \mu)$, bearing at the free end a secondary flexuose narrower appendage, 50-60 $\mu$ long, which soon disappears, apical appendage longer than the spore, evanescent.

Hab.-On dung of Mexican Deer (Cariacus mexicanus), Kew, Jan. I90I. (Distrib.-Germany, on dung of Hare.)

As Winter points out, the present Fungus differs from $S$. fimiseda, Ces. and De Not., only in the smaller spores, which are about half the size of those of that species. If this difference were constant, it might be considered to afford a specific character, but Winter expressly states that he has found spores intermediate in size. It seems best, therefore, to place the present plant as a variety under $S$. fimiseda-the nature and development of the appendages of the spore being quite similar in both cases. As Winter (Deutsch. Sordar. p. 90) has remarked, the basal appendage, which appears first, represents a true cell, and is quite different in origin from the two secondary appendages: 'Dass diese Anhängsel auch morphologisch verschieden sind, wurde schon gesagt; das an der Basis der Spore direct ansitzende ist eine specifische Zelle, die beiden anderen offenbar nur gallertartigquellende Verdickungen der Membran der Spore und des Hauptanhängsels.'

The example here recorded on the dung of Mexican Deer differs apparently from the usual form, which is described as 'covered all over with short septate hairs,' in the longer denser hairs of the perithecium, and the compact apical tuft.

Sordaria sp. (Fig. I 7).

A remarkable form, or species, of Sordaria occurred on Kangaroodung exposed for some months to the open air. The perithecia were black, rather large $\left(\frac{3}{4}-1 \mathrm{~mm}\right.$. high, $\frac{1}{2} \mathrm{~mm}$. wide), densely crowded, and held together at the base by a byssoid stroma composed of brown interwoven hyphae. The most remarkable feature, however, was the wall of the perithecium, the external cells of which were nearly all transformed into broad-based spine- or prickle-like structures, each composed of a single cell. Each prickle-like cell (Fig. I 7) measured 
from $30-60 \mu$ across the base. Only a few spores were seen, measuring $20-22 \times 10-12 \mu$, and provided at one end with a rather long hyaline appendage. The asci seen were few, and ill-developed, and it seems therefore possible that the present form is to be regarded as a monstrous development of some species of Sordaria, induced by unfavourable (abnormal) conditions. It may be mentioned that the Kangaroo-dung was fully exposed to the effects of the weather, and for a few days was buried under a heavy fall of snow.

S. fimicola (Rob.), Ces. and De Not.; Wint., Deutsch. Sordar. 8I, Taf. VII, f. 6 (1873); Sacc. Syll. Fung. i, 240 (1882), sub Hypocopra.

Hab.-On the dung of Elephant (Elephas africanus), Hare (Lepus europaeus), and Kangaroo (Macropus giganteus), Kew, Dec. I900.

On the Elephant's dung the perithecia are quite superficial, and only very loosely attached to fragments of straw, \&c. The layer of mucilage surrounding the spores (which are minutely pointed at one end just as in $S$. macrospora, Auersw.) is usually rather wide, measuring $4-5 \mu$ across at each side of the spore.

S. platyspora, Plowr., in Grevill. vi, 28 , Tab. XCIV, f. 2 (I877); Sacc. Syll. Fung. i, 24 I (I882), sub Hypocopra.

Hab.--On Horse-dung, Kew Green, and Hastings, England, Dec. I 900 .

The Kew specimens are remarkable for the irregularity in the shape of some of the ascospores, which instead of showing the normal almost circular form (when seen from the front), have a nearly square or irregularly waved outline.

S. curvula, De Bary; Wint., Deutsch. Sordar. Ior, Taf. XI, f. 22 (1873); Sacc. Syll. Fung. i, 233 (I882).

Hab.-On the dung of Mexican Deer (Cariacus mexicanus), Giraffe (Camelopardalis giraffa), and Elephant (Elephas africanus), Kew, Oct. 1900.

On the dung of the first-named animal the perithecia were quite superficial, and attached by a dense weft of colourless hyphae.

S. minuta, Fckl.; Wint., Deutsch. Sordar. ıoo, Taf. XI, f. 2 I (I873); Sacc. Syll. Fung. i, 23 I (I882).

Hab.-On Rabbit-dung, Kew, Dec. I900, with tetrasporous asci; on the dung of Mexican Deer (Cariacus mexicanus) and Sinaitic Ibex (Capra sinaitica), Kew, Jan. I90I, with octosporous asci; on the dung of Kangaroo (Macropus giganteus), Kew, Feb. I901,-a form with eight somewhat lemon-shaped, inaequilateral spores. 
S. decipiens, Wint., Deutsch. Sordar. 92, Taf. IX, f. I6 (I873); Sacc. Syll. Fung. i, 235 (1882).

Hab.-On Rabbit-dung, Kew, Dec. I900; on the dung of Giraffe (Camelopardalis giraffa), Mexican Deer (Cariacus mexicanus), and Sinaitic Ibex (Capra sinaitica), Kew, Dec. 1900.

The Kew examples are very interesting on account of the variation shown in the number of spores in the ascus. $S$. decipiens has been described by all authors as having 8 -spored asci; in some of the Kew examples, however, perithecia occurred in which all the asci contained sixteen spores. It was quite clear, moreover, that the same species, viz. S. decipiens, was under observation, as in one perithecium, from another gathering on Rabbit-dung, two asci each containing sixteen spores were present among the normal octosporous ones. In Saccardo's 'Sylloge' only the species of Sordaria with four and eight spores in the ascus are included under that genus, the species with 'polysporous' asci (i.e. asci containing sixteen or more spores) being removed to another genus, Philocopra. Such specific variation as that recorded above shows the artificiality of genera founded merely on the number of spores in the ascus.

S. stercoraria (Sowerb.).

Sphaeria stercoraria, Sowerb., Brit. Fung., t. 357 (1803).

Hypocopra stercoraria, Sacc. Syll. Fung. i, 244 (I882).

An examination of the type specimen at Kew shows that in this species the spores, which are elliptical and laterally compressed, and surrounded by a layer of mucilage, measure $45^{-60} \times 22-3^{8} \mu$. The measurement-' $30 \mu$ long'-given by Saccardo, therefore, requires correction.

S. coprophila (Fr.), Ces. and De Not.

Sphaeria bovilla, Cooke, Handb. Brit. Fung., ii, 874, Fig. 394 (I 87 I).

Bovilla Capronii, Sacc. Syll. Fung. ii, 360 (1883).

The Fungus called by Cooke Sphaeria bovilla has been made by Saccardo the type of a new genus Bovilla. Examination of Cooke's material (now in the Kew Herbarium) shows, however, that the Fungus is merely the immature stage of Sordaria coprophila. The genus Bovilla, being founded on this single specimen, must therefore be abolished.

Delitschia moravica, Niessl. (Fig. I8).

D. moravica, Niessl., Notiz. Pyren. 47, Taf. IV, f. 22 (1876); Sacc. Syll. Fung. i, 733 (1882); Wint. in Rabenh. Krypt.-Fl. Deutschl., Bd. i, 
Abth. 2, I79 (1887); Schroet. in Cohn's Krypt.-Fl. Schles., Bd. iii, Hälfte 2, 290 (1894).

Perithecia minute, about $\frac{1}{4} \mathrm{~mm}$. high, at first subimmersed, but becoming almost free, subgregarious, subglobose, with a short thick blunt blackish neck, which is covered with short scattered rigid dark setae; asci narrowly cylindrical, I 70-200 $\times$ I $2-18 \mu$; spores obliquely I-seriate or sometimes irregularly biseriate, oblong or ellipsoid, straight, constricted at the septum, provided at each end with a minute subhyaline wart-like apiculus, $20-22 \times 8-9 \mu$, surrounded by a narrow layer of mucilage.

Hab.-On Rabbit-dung, Reigate, England, Nov. 1900. (Distrib.-Austria-Hungary, on dung of Hare.)

The bristly perithecia and the wart-like apiculus of the spores distinguish the present species from the commoner D. minuta, Fckl.

D. insignis, Mout. (Fig, 20).

D. insignis, Mout., in Bull. Soc. Roy. Bot. Belg. xxxvi, part 2, I3, t. A, ff. 7,8 (1897); Sacc. Syll. Fung. (Supp.) xiv, $55^{8}$ (1900).

Perithecia about I $\mathrm{mm}$. high, more or less scattered, immersed, glabrous, basal part globose-ovate, olivaceous, narrowed upwards into a rather long, cylindrical, stout, blackish-brown neck; asci elongatecylindrical, $300-320 \times 25-3 \circ \mu$, rounded at the apex, gradually narrowed below into the stalk, 8-spored; paraphyses septate, filiform, often branched, longer than the asci ; spores biseriate, oblong, somewhat rounded at the ends, deeply constricted and eventually separating at the septum, $44-67 \times 10-16$ (rarely 20 ) $\mu$, provided at each end with a hyaline straight or flexuous appendage about equalling the spore in length.

Hab. - On Horse-dung, Epping Forest, Essex, Oct. 1900, and Kew, Nov. I 900. (Distrib.-Belgium, on Cow-dung.)

We are indebted to Prof. Saccardo for the identification of this species. D. insignis is a fine and well-marked species, and it is somewhat remarkable that it has for so long escaped notice. The plant was originally discovered by Mouton (1.c.) in 1897, on Cow-dung, in Belgium, and this remained the only locality known until in November last we met with the species on Horse-dung in Epping Forest. It is possible that $D$. insignis may occur not uncommonly in this country, as a search on Horse-dung at Kew at once resulted in finding the species. D. insignis, together with another species-D. sordarioides, Speg., from S. America -are peculiar in the genus in possessing caudate appendages in the 
place of the layer of mucilage which surrounds the spores of most species of Delitschia. On account of this difference the question has been raised as to whether these two species can be placed in the genus Delitschia. There seems, however, every reason for doing so when we remember that we find in the related genus Sordaria certain species (S.macrospora, S. fimicola, \&c.) with spores surrounded by a layer of mucilage, while other species have one or two caudate appendages to their spores. Mouton (1.c.) observes of the spores of D. insignis, after describing them as 'medio septata,'- - nonnunquam ad quartam partem inferiorem tenuiter (spurie?) septata.' In our specimens, however, the only septum observed was at the middle, where the spore is much constricted. At this place the spore, at maturity, falls readily into two halves, each of which may for a little time retain its tail, but the latter finally becomes completely absorbed, and each half of the spore appears then as a more or less elliptical cell.

D. Winteri, Plowr. (Fig. 22).

D. Winteri, Plowr., in Grevill. ii, $\mathbf{I} 88$, Tab. XXV, f. I (1874); Wint. in Hedwigia, xiii, 52, f. 3 (1874); Sacc. Syll. Fung. i, 734 (1882).

Hab.-On Rabbit-dung, Reigate, England, Nov. I $900 . \quad$ (Distrib.England, N. Italy, Belgium, on dung of Rabbit, Hare, Cow, and Sheep.)

This species does not seem to have been hitherto met with in England, since it was originally discovered by Plowright at King's Lynn, Norfolk, in 1873. The following diagnosis is drawn up from our specimens: Perithecia scattered, almost completely immersed, up to $\mathrm{I} \mathrm{mm}$. high, $\frac{1}{2}-\frac{1}{3} \mathrm{~mm}$. broad, glabrous, basal part ovate-globose, olivaceous, narrowed upwards into a thick bluntly conical blackish brown neck, cells of perithecial wall $\mathbf{1 0 - 1} 5 \mu$ wide ; asci large, elongatecylindrical, about $500 \mu$ long and $40-45 \mu$ wide, narrowed below into a short stalk, 8-spored; spores obliquely uniseriate, broadly oblong, obtuse at both ends, slightly constricted at the septum, opaque, darkfuscous, $5^{0-60} \times 25^{-28} \mu$, surrounded by a layer of mucilage. $D$. Winteri agrees so closely in nearly all its characters with $D$. Auerszvaldii, Fckl., that it is possible that the two are not specifically distinct. In both we find the large spores (variable in length), slightly constricted at the septum, and bluntish at the ends, the only difference being that in $D$. Winteri the spores are from $25^{-28} \mu$ wide, while in $D$. Auerswaldii, judging from the examples in Fckl., Fung. Rhen. 2034, they appear to average about $20 \mu$. It must be mentioned, 
however, that many authors describe the spores of $D$. Auerswaldii as narrower than this, Winter giving the measurement $16 \mu$, Saccardo I $8 \mu$, and Schroeter I $7-2$ I $\mu$.

Sporormia longipes, sp. nov. (Fig. I).

Peritheciis sparsis plus minus superficialibus subglobosis glabris atris $\frac{1}{4}-\frac{1}{2} \mathrm{~mm}$. diam., ostiolo brevi obtuso, contextu membranaceo parenchymatico e cellulis distinctis parvis (circiter $5 \mu$ ) composito; ascis late clavatis vel elongato-clavatis in stipitem longissimum $(50-80 \mu)$ angustum saepe flexuosum attenuatis, octosporis, $120-\mathrm{I} 45 \times \mathrm{I} 5^{-20} \mu$; sporis asci apicem versus imbricato- 3 -stichis, cylindraceis, utrinque rotundatis, rectis vel parum curvatis, quadrilocularibus, $26-33 \times 6-8 \mu$, primum fuligineis demum fuscis, facile secedentibus, articulis mediis minoribus subquadratis $5^{-6} \mu$ longis, terminalibus longioribus oblongis ellipticisve.

Hab.-In fimo Cariaci mexicani (Mexican Deer), Capreoli capraeae (Common Roe), Camelopardalis giraffa (Giraffe), Caprae dorcadis (Dorcas Goat), Caprae sinaiticae (Sinaitic Ibex), Kew, Dec.-Feb. I90I.

Inter species affines ( $S$. leporinam, Niessl., $S$. Notarisiz, Carestia) ascis longe- stipitatis distinguenda.

The shape of the ascus varies in the present species from elongateclavate to broadly clavate or (in outline) almost battledore-shape. The ascus is, however, always long stalked, and this character distinguishes $S$. longipes from the allied species of Sporormia with tetramerous spores. S. corynespora, Niessl., a species with octomerous spores, approaches the present species in its long-stalked asci. In $S$. longipes the spores remain steel-grey in colour for a long time, but finally become brown.

S. ovina (Desmaz.), Sacc. (Fig. 4).

Hormospora ovina, Desmaz., in Ann. sci. nat., $3^{\mathrm{e}}$ sér. (Bot.), xvi, $3 \mathbf{I} 7$ (185I); Pirotta, Mon. Spororm., I6r (I878).

S. ovina, Sacc. Syll. Fung. ii, I 27 (1883).

S. gigantea, Hans., in Vidensk. Meddel. I876, p. 3 19, Tab. VI, f. $46 \& 47$ (1876-77); Speg. in Michel. i, 23 I (1878); Niessl. in Oest. Bot. Zeit. xxviii, I23 (I878); Pirotta, Mon. Spororm. I48 (I878); Sacc. Syll. Fung. ii, I 27 ( 1883 ) ; Wint. in Rabenh. Krypt.-Fl. Deutschl., Bd. i, Abth. 2, 183 (1887).

Perithecia dark brown or black, scattered, glabrous, subimmersed, basal part subglobose narrowed upwards into a rather thick conical or subcylindrical neck ; asci oblong or oblong-clavate, narrowed below into 
a distinct stalk, 8-spored, $320-370 \times 50-55 \mu$, spores 2-4-seriate, I 20I $55 \times$ I $7-20 \mu$, imbricate and arranged in subparallel rows, elongatecylindrical, straight or (usually) slightly curved, tetramerous, deeply constricted and readily separating at the septa, median cells oblong or cylindric with square ends, terminal cells elongate-conoid, each spore surrounded by a rather broad layer of mucilage.

Hab.-On Rabbit-dung, Kew, Jan. I 9o I. (Distrib.-France, N. Italy, Denmark, Germany ; on dung of Sheep and Cow.)

A comparison of Desmazière's 'Hormospora ovina' in Desmaz. Crypt. Fr., $2^{\ominus}$ ser., nr. 98, with authentic specimens (coll. Hansen) of $S$. gigantea, Hans., in the Kew Herbarium, shows the two plants to be identical, and as ovina is the older specific name, this must be used for the present Sporormia.

S. pulchella, Hans. (Fig. 2).

S.pulchella, Hans., in Vidensk. Meddel. 1876 , p. 320 , Tab. IX, ff. $23-$ 25 (1876-77); Pirotta, Mon. Spororm. I45 (1878); Niessl. in Oest. Bot. Zeit. xxviii, 95 (1878); Sacc. Syll. Fung. ii, I23 (1883); Wint. in Rabenh. Krypt.-Fl. Deutschl., Bd. i, Abth. 2, I8I (I887).

Perithecia gregarious or scattered, black, almost spherical, with a very short bluntly conical or papilliform neck, about $\frac{1}{4} \mathrm{~mm}$. across, almost completely immersed ; asci numerous, narrowly long-cylindrical, sometimes flexuose, rounded at the apex, narrowed below into a stalk, I I0-I 50 $\times$ 9-IO $\mu, 8$-spored; paraphyses numerous, delicate, filiform, septate, sometimes branched, about as long as the asci; spores uniseriate, subcylindrical, straight or curved, $\mathbf{I}_{7}-20 \times 5 \mu$, surrounded at first by a narrow layer of mucilage, tetramerous, constricted at the septa and readily separating, median cells somewhat barrel-shaped, terminal cells conical or subovate.

Hab.-On Horse-dung, Kew Green, England, Dec. I 900. (Distrib.Denmark, Austria ; on Cow- and Sheep-dung.)

$S$. pulchella is easily recognized by the numerous narrowly.cylindrical asci with uniseriate spores.

S. fimetaria, De Not. (Fig. I9).

S. fimetaria, De Not., Micr. ital. dec. v, p. ro (1849); Auersw. in Hedwigia, vii, 69, Tab. I, f. vi (1868); Pirotta, Mon. Spororm. I6o (1878); Sacc. Syll. Fung. ii, $\mathbf{I}^{2}$ (1883); Wint. in Rabenh. Krypt.Fl. Deutschl., Bd. i, Abth. 2, 187 (1887).

Hormospora fimetaria, De Not., in Giorn. Bot. Ital., tome ii, 47 (1884). 
Sphaeria fimetaria, Rabenh. Herb. Myc., ed. I, nr. I 733.

Perithecia densely gregarious, small, I $40-175 \mu$ in diam., subglobose with a minute papilliform ostiolum, wall membranous, parenchymatous, composed of rather distinct cells up to $10 \mu$ wide; asci numerous, shortly cylindrical, usually slightly curved, $60-75 \times$ I $3^{-1} 5 \mu$, narrowed below into a very short stalk, 8-spored, spores arranged parallel to each other, forming a single bundle in the ascus, narrowly longcylindrical, $48-50 \times 4 \mu, \mathbf{I} 5^{-1} 8$-celled, segments readily separating, middle segments broader than long, $2.5 \mu$ long, two end segments about $4.5 \mu$ long.

Hab.-On Cow-dung, Aboyne, Scotland (Herb. Berk.). (Distrib.Europe: Germany, Italy; N. America: U. S. A., South Carolina ; on Cow-dung.)

$S$. fimetaria is one of the most distinct species of the genus, and is at once recognized by the parallel arrangement of the long, narrow, many-celled ascospores, which are collected into a single fascicle in the ascus. The fungus described under the name 'Sporormia fimetaria, De Not.' by Schroeter in Cohn's Krypt.-Fl. Schles. is evidently, from the characters given, specifically distinct from the present plant. The examples of $S$. fimetaria from the United States (Aiken, S. C., Ravenel, nr. $226_{3}$ ) are in the Kew Herb., and agree exactly with the European plant.

S. minima, Auersw.; Sacc. Syll. Fung. ii, I 24 (1883).

Hab.-On dung of Giraffe (Camelopardalis giraffa) and Dorcas Goat (Capra dorcas), Kew, Dec. I 900.

S. intermedia, Auersw.; Sacc. Syll. Fung. ii, I 26 (1883).

Hab.-On dung of Giraffe (Camelopardalis giraffa), Dec. 1900; on Rabbit-dung, Reigate, Dec. I900; on Horse-dung, Epping Forest, Oct. 1900.

S. megalospora, Auersw. ; Sacc. Syll. Fung. ii, I26 (I883).

Hab.-On Horse-dung, Kew Green, Dec. 1900.

Sporormiella nigropurpurea, Ell. \& Everh. (Fig. 3).

S. nigropurpurea, Ell. \& Everh., N. Amer. Pyren., I36 (1892); Sacc. Syll. Fung. xi, 330 (1895).

Perithecia soft, carnose, aggregated into groups and forming more or less extended continuous black patches; asci numerous, I I0-I 40 $\times$ Io-I I $\mu$, narrowly cylindrical, often flexuose, narrowed below into a stalk, 8-spored; paraphyses numerous, filiform, very slender ; spores usually biseriate in the upper part of the ascus, subcylindrical, I 8- 


\section{Coprophilous Fungi.}

$20 \times 5^{-6 \mu}$, surrounded at first by a narrow layer of mucilage, nearly straight, tetramerous, median cells subglobose, terminal cells subovate.

Hab.-On Cow-dung, Kew, Jan. I yor. (Distrib.-United States (New Jersey), on Cow-dung.)

The Kew specimens are identical with authentic examples (coll. Ellis) of Sporormiella nigropurpurea in the Kew Herbarium. The genus Sporormiella was founded by Ellis and Everhart (1.c.) with the following characters: 'Perithecia soft carnose, embedded in a flattish semi-immersed subcarnose stroma. Asci and sporidia as in Sporormia.' Only the single species $S$. nigropurpurea of the same authors is known, and in this the perithecia are described as 'buried in the soft flattish stroma, which is $\frac{1}{2}-1 \mathrm{~cm}$. across, or by confluence more, slightly raised above the surface of the matrix, dark grey outside, and, like the perithecia, purplish black within.' A true stroma, however, such as is indicated by the above description, was not found either in Ellis' New Jersey specimens, mentioned above, nor in the Kew examples; in both cases the soft carnose perithecia being only aggregated into continuous patches. It must be noted that the presence of a definite stroma is the only character relied upon to separate the present genus from Sporormia. Moreover, except in the dense grouping of the perithecia, and in the ascospores being usually biseriate instead of uniseriate, both the Kew and Ellis' specimens agree so closely in all characters with Sporormia pulchella, Hans., that even the specific distinctness of the present plant seems almost doubtful.

Microascus variabilis, sp. nov. (Fig. 24).

Peritheciis gregariis matrice subimmersis parvulis I 50-200 $\mu$ diam., subglobosis, ostiolo minuto papilliformi vel plus minus elongato cylindraceo interdum flexuoso, nigris, subcarbonaceis, fragilibus, contextu parenchymatico e cellulis densis opacis distinctis minutis $3-5 \mu$ latis composito, perithecii parte superiore pilis rigidis paucis sparsis fuligineis interdum obsoletis instructa, ascis minutis subglobosis subgelatinosis 7-8 $\mu$ diam., citissime diffluentibus octosporis ; sporis crasse (interdum irregulariter) lunulatis, minutis, $3-3.5 \mu$ longis, utrinque obtusis, levibus, dilutissime brunneis.

Hab.-In fimo Dolichotidis patachonicae (Patagonian Cavy), Kew, Jan. I90r.

The above species seems to be allied to $M$. longirostris, Zukal, but differs in the shorter or even obsolete neck of the perithecium, the much smaller asci, and the smaller spores, with obtusely rounded, not 
acute, ends. The spores of $M$. variabilis, seen in the mass, have a faint brownish tinge; we were not able to observe any layer of mucilage surrounding each spore, as Zukal has recorded in the case of $M$. longirostris. The asci are extremely evanescent, and difficult to see-the perithecium containing as a rule only free spores. The latter are usually broadly lunulate in outline, and somewhat flattened; sometimes, however, they are slightly irregular in shape. The variability in the shape of the perithecium is very marked-the ostiolum being sometimes papilliform or even hardly visible, at others welldefined and forming a distinct more or less cylindrical neck, which is sometimes flexuous.

M. nidicola, sp. nov. (Figs. 62-65).

Peritheciis nigris glabris carbonaceo-membranaceis sparsis matrice subimmersis subglobosis $\frac{1}{3} \mathrm{~mm}$. diam. ostiolo brevi conico, contextu parenchymatico densissimo e cellulis polygonis nigro-fuscis plus minus opacis 8-10 $\mu$ latis composito; ascis numerosis subgelatinosis ellipticis vel globoso-ellipticis IO-I $3 \times 6-8 \mu$ octosporis citissime diffluentibus; sporis minutis anguste sublunulatis utrinque acutis laevibus hyalinis vel stramineis $7 \cdot 5^{-8} \times 2 \mu$.

Hab. - In nido vetusto Bombi sp., sociis Myxotricho setoso (Eidam), Schroet., et Arachnioto candido (Eidam), Schroet., Kew, Mar. I90 I.

$M$. longirostri, Zukal, sporis lunulatis comparanda, sed perithecii forma et glabritate, ascis minutis nec non sporis angustioribus majoribus longe recedens.

The above species occurred sparingly on an old nest of a Wild-bee (Bombus sp.). The nest, which was dug up in the Royal Gardens, Kew, was covered on the surface with large patches of Myxotrichum setosum and Arachniotus candidus. The wall of the perithecium, unlike that of $M$. variabilis, is very dense and opaque, so that its cellular structure is not readily apparent. The asci are subgelatinous, and very quickly dissolve in water, setting free the narrow somewhat lunate-shaped spores. The spores become finally of a pale straw colour, and the ascus itself is sometimes tinged with the same colour.

Spumatoria, gen. nov.

Perithecia subglobosa, semi-immersa, demum superficialia, mẹmbranacea, in rostrum longum cylindraceum apice fimbriatum plus minus dilatatum attenuata, ascis tenuibus, evanescentibus, octosporis, sporis didymis, hyalinis, demum in spuma mucilaginosa ex ore rostri ejectis; paraphysibus indistinctis. 
S. longicollis, sp. nov. (Fig. 27).

Peritheciis sparsis $0 \cdot 75^{-I} \mathrm{~mm}$. altis semi-immersis demum superficialibus subglobosis olivaceis membranaceis contextu parenchymatico e cellulis polygonis $6-10 \mu$ latis composito glabris vel basi hyphis repentibus instructis, in rostrum longissimum cylindricum atrum rugulosum apice fimbriatum plus minus dilatatum abrupte attenuatis; ascis cylindraceis, I IO-I $30 \times 1 \mathbf{I}^{-1} 5 \mu$ deorsum in stipitem attenuatis, octosporis, citissime diffluentibus; sporis monostichis oblongis utrinque rotundatis $\mathbf{I} 5-\mathbf{I} 9 \times 5 \mu$ hyalinis $\mathbf{I}$-septatis medio haud constrictis demum in spuma mucilaginosa ex ore rostri ejectis; conidiis in eodem perithecio productis, oblongis, hyalinis, $\mathbf{I} 7-20 \mu$ longis, I-septatis, basi plus minus attenuatis, in conidiophoris simplicibus brevibus acrogenis.

Hab.-In fimo equino, Epping Forest, Essex, October, 1900.

The perithecia of the present fungus, which appeared on some Horse-dung soon after it was collected, readily attract attention by reason of the long upright black cylindrical beaks. At maturity the spores are seen issuing forth from the apex of the beak in the mucilage formed by the deliquescence of the asci, \&c. The mouth of the beak is composed of loosely arranged easily separating hyphae, which during the ejection of the spores are forced apart by the mucilaginous mass, so that the apex of the beak at this time is more or less dilated.

The conidia precede the asci in the same perithecium, and the Fungus in this stage appears to be identical with Rhyncophoma, Karst. emend. (see Allescher, in Rab. Krypt.-Fl. Deutschl., 6. Abth., vol. i, p. 7 II $)$.

Xylaria pedunculata (Dicks.), Fr.; Sacc. Syll. Fung. i, 332 (1882). Sphaeria pedunculata, Dicks., Pl. Crypt. Brit. iv, 27 , Tab. XII, f. 8 (I80r).

The spores in Dickson's type-specimen measure $50 \times 22-24 \mu$, and so slightly exceed the measurement $\left({ }^{\prime} 40 \times 20\right.$ ') given by Saccardo, \&c.

Hуроcraeaceae. Sphaeroderma fimbriatum, Rostr. (Fig. 23).

S. fimbriatum, Rostr., in Meddel. om Groenland, xviii, 67 (1895); Sacc. Syll. Fung. xi, $35^{6}$ (1895).

Perithecia scattered or subgregarious, superficial, about $\frac{1}{8} \mathrm{~mm}$. diam., globose with a mamilliform ostiolum, which is surmounted by a tuft of short $(60-100 \times 4-6 \mu)$ rigid colourless hairs, otherwise glabrous or with a few spreading hyphal outgrowths near the base, at first yellowish, 
becoming dull red, wall thin, soft, membranous, composed of rather large (10-20 $\mu$ wide) irregularly shaped cells; asci obovate or subpyriform, $80-100 \times 22-25 \mu$, rounded at the apex, narrowed below into an evident stalk, 8-spored; spores inaequilateral, somewhat lemon-shaped, 2 I-2 $5 \times$ Io-I I $\mu$, fuliginous, opaque.

Hab.-On the dung of Guinea Pig, Kew ; Jan. I901. (Distrib.E. Greenland, on dung of Reindeer.)

The above species occurred associated with Pleuroascus Nicholsoni (see p. 330). The hairs, forming a tuft round the ostiolum, ar : often somewhat swollen at their base (Fig. 23). We have not seen an authentic specimen of Rostrup's species, but the author's description, given below, seems to point to the present plant: 'Perithecia minima, sphaeroidea, rubella, ostiolo fimbriato, subiculo obsoleto; asci cylindraceo-clavati, longit. Iо०-I $10 \mu$, crass. $20 \mu$; sporae distichae, initio hyalinae, dein fuscae, ellipsoideae, long. $20 \mu$, crass. I I-I $2 \mu$.'

s. Hulseboschii, Oudem. (Figs. 57-6I).

S. Hulseboschii, Oudem., in Nederl. Kruid-Archief, ser. 2, iv. 523 (1886); Sacc. Syll. Fung. ix, 949 (I891).

Perithecia scattered or subgregarious, superficial, $\frac{1}{4}-\frac{1}{2} \mathrm{~mm}$. in diam., yellowish or with a reddish tinge, subglobose with a minute ostiolum, which is surrounded by short (about $3 \circ \mu$ long) colourless hairs, wall of perithecium soft, thin, composed of rather large, irregularly shaped cells, about $I_{5}^{-20} \mu$ wide; asci pyriform, 50-60 $\times 25 \mu$, 8-spored, evanescent; spores arranged in two or three rows towards the apex of the ascus, lemon-shaped, often inaequilateral, minutely truncate at each end, $18-20 \times 9-10 \mu$, at first colourless, then pale olivaceous, becoming finally fuliginous and opaque, the tip at each end of spore remaining pallid for some time.

Hab.-On Rabbit-dung, Leith Hill, Surrey, England, Mar. I90 I. (Distrib.-Netherlands, on Rabbit-dung.)

The spores of the present species are lemon-shaped, and minutely truncate at each end. As is noted in Oudeman's original description, the extreme ends of the spore commonly remain subhyaline for some time after the rest of the spore has become dark-coloured.

Melanospora discospora, sp. nov. (Figs. $3^{6-3^{8}}$ ).

Peritheciis sparsis rare subgregariis minutis I IO-I $30 \mu$ diam. I80$200 \mu$ altis subimmersis glabris subglobosis flavicantibus membranaceis contextu parenchymatico molli tenui e cellulis irregularibus circiter $10 \mu$ latis composito rostro breve-cylindraceo recto obtuso $60-80 \mu$ 
longo apicem versus subhyalino; ascis oblongis circ. $35 \times 14 \mu$, octosporis citissime diffluentibus sporis discoideis a fronte orbicularibus 7-9 $\mu$ diam., a latere ellipticis $4 \mu$ latis atrobrunneis, ad rostri apicem singulatim eructatis et tandem massam subglobosam nigrum formantibus.

Hab.-In fimo Caprae sinaiticae (Sinaitic Ibex) et Ovis burrhel (Burrhel Wild Sheep), Kew, Mar. I89 I.

A congeneribus sporis discoideis statim dignoscenda.

The minute perithecia, when perfectly ripe, attract attention from the black globular mass of spores at the apex of the beak. Each spore is singly expelled from the basal part of the perithecium up the neck, and in the process of being discharged is clearly visible in the nearly hyaline upper part of the beak. The spores are very dark brown, and perfectly discoid in shape.

\section{BIBLIOGRAPHY.}

1. Auerswald, B.: Die Sporormia-Arten. Hedwigia, vii, 65-72, Taf. I. (I868.)

2. BainieR, G. : Observ. sur les Mucorinées. Ann. sci. nat., $6^{\circ}$ sér., xv, 70-104, Pls. IV-VI. (1883.)

3. Baranetzky, J. : Entwickelungsgesch. des Gymnoascus Reessii. Bot. Zeit., $\mathrm{xxx}, \mathrm{I} 45^{-1} 59$, Taf. III, A. (I872.)

4. Boudier, E.: Mém. sur les Ascobolés. Ann. sci. nat., $5^{\ominus}$ sér., x, I91-268, Pls. V-XII. (I 869.$)$

5. BREFeld, O.: Untersuch. aus dem Gesammtgeb. d. Mykolog., ix, II3-I18, Taf. III, A. (I89I.)

6. - Loc. cit., $x, 337-339$. (I89I.)

7. Chelchowski, S. : Fungi Fimicoli Polonici., Physiogr. Denkschr., Warschau, Bd. xii. (I892.)

8. Coemans, E.: Monogr. du genre Pilobolus. Mém. Cour. Acad. Bruxelles, xxx, I-68, Pls. I-XI. (I86I.)

9. - Notice sur les Ascobolus de la Flore Belge. Bull. Soc. Roy. Bot. Belg., i, 76-9I. (I862.)

10. Cooke, M. C. : The genus Ascobolus. Journ. of Bot., ii, I47-I 54. (I 864.)

11. Crouan, P. L. and H. M. : Note sur neuf Ascobolus nouveaux. Ann. sci. nat., $4^{\circ}$ sér., $\mathrm{x}, \mathrm{I} 93^{-1}$ 99, Pl. XIII. (I858.)

12.

13. De Bary, H. A. : Vergleich. Morph. u. Biol. d. Pilze, Mycet. u. Bacter. 376. (I884.)

14. Gilkinet, A.: Rech. morphol. sur les Pyrenomycetes, I (Sordariées). Bull. Acad. Roy. Sci. et Lettres, \&c., $2^{\ominus}$ sér., t. xxxvii, 426-449, Pls. I-II. (I874.) 
15. Hansen, E. C.: Fungi fimicoli danici. Vidensk. Meddel., 1876, 207-354, Tab. IV-IX. (I876-7.)

16. Biolog. Untersuch. über Mist-bewohnende Pilze. Bot. Zeit., lv, III-I 32, Taf. II. (I897.)

17. Heimerl, A.: Die niederösterr. Ascoboleen. XV. Jahresber. d. k. k. OberRealsch., Bezirk Sechshaus, Wien, I-32, Taf. I (in sep.). (I889.)

18. Janczewski, E. v. G. : Morph. Untersuch. über Ascob. furfuraceus. Bot. Zeit., xxix, 257-262, Taf. IV. (I87 I.)

19. Karsten, P. A.: Monogr. Ascobolorum Fenniae. Notiser Faun. Flor. Fennica, xi, 197-210. (I870.)

20. Marchal, E.: Champ. Coproph. de la Belgique, I-VII. Bull. Soc. Bot. Belg., t. xxiii (2), 9-I7, 59-6I, 88-94 (I884); t. xxiv (I), 57-77, Pl. I-IV (I885); t. xxviii (I), 26I-27I, Pl. X (I889); t. $\operatorname{xxx~(2),~}$ I 34-I46 (I89I); t. xxxiv, I 28-I 49, Pl. I, II (I895).

21. MASSEE, G. : Brit. Fung. Fl., iv, I55-185. (I895.)

22. Revision of the genus Coprinus. Ann. of Bot., $x, 123-184$, Pl. X, XI. (I896.)

23. Matruchot, L. : Structure, développement et forme parfaite des Gliocladium. Rev. Gén. de Bot., vii, 32 I-33I, Pl. XVI. (1895.)

24. Mouton, O.: Ascomycètes observ. aux envir. de Liège. Bull. Soc. Bot. Belg., xxv, pt. I, I37-I62, Pl. IV. (I886.)

25. Niessl, G. voN : Beitr. zur Kenntn. d. Pilze. Verh. d. Naturf.-Vereins, Brünn, $x$ (Abhandl.), pp. 187-193, Taf. V, VI. (1872.)

26. Ueber Sordaria appendiculata (Auwd.) und S. curvula, De By. Hedwigia, xii, I6I-163. (1873.)

27. Die Arten der Pyrenomycetengattung Sporormia (De Not). Oest. Bot. Zeit., xxviii, 4I-45, 95-98, I 2 I-I 24, I63-I68. (I878.)

28. Palla, E. : Zur Kenntnis d. Pilobolus-Arten. Loc. cit., 1, 350-370, 39740I, Taf. X. (I900.)

29. Pirotta, R. : Saggio d'una Monograf. del gen. Sporormia. Nuov. Giorn. Bot. Ital., x, I $27-16_{3}$, Tav. VI. (I878.)

30. Popta, C. M. L. : Beitr. zur Kenntnis der Hemiasci. Flora, lxxxvi, I-46, Taf. I-II. (1899.)

31. ReHм, H. : In Rabenhorst's Krypt.-Fl. Deutschl., Bd. i, Abth. 3, pp. 1078II 34. (I896.)

32. Renny, J.: New Species of the genus Ascobolus. Journ. of Bot. (n. ser.), iii, 353-357, P1. CLIII-CLVI. (1874.)

33. Rostrup, E. : Oest. Groenl. Svampe. Meddel. om Groenland, xviii, 6r. (I895.)

34. SacCardo, P. A.: Sylloge Fungorum, xii, Pars I, 3, 873-902. (1897.)

35. Schroeter, J.: in Cohn's Krypt.-Fl. Schles., Bd. iii, 2. Hälfte, p. 5 r. (1893.)

36. Smith, A. L. : Fungi new to Britain. Trans. Brit. Myc. Soc., I898-99, p. II 5 .

37. Spegazzini, C. : Fungi coproph. Veneti. Michel., i, 222-238. (1878.)

38. Tieghems, P. van, and Le Monnier, G. : Recherches sur les Mucorinées. Ann. sci. nat., $5^{\circ}$ sér., xvii, 261-399, $\mathrm{Pl}$. XX-XXV. (1873.)

39. - Nouv. recherches sur les Mucorinées. Ibid., $6^{\circ}$ sér., i, 5-I 75, Pl. I-IV. (I875.) 


\section{Coprophilous Fungi.}

41. Winter, G.: Einige Bemerk. zu Niessl's Beitr. zur Kenntnis der Pilze. Bot. Zeit., xxx, 833-836. (1872.)

42. - Einige vorläuf. Mitth. über die Gattung Sordaria. Bot. Zeit., $\mathrm{xxxi}, 449-453,465-469,48 \mathrm{I}-485$. (I873.)

43. Die deutschen Sordarien. Abhandl. d. Naturf.-Gesell. zu Halle, xiii, $65-107$, Taf. VI-XI. (I873:)

44. - Mykolog. Notizen. Hedwigia, xiii, 50-57. (1874.)

45. - In Rabenhorst's Krypt.-Fl. Deutschl., Bd. i, Abth. 2, pp. I62I87. (I887.)

46. Woronin, M.: Sordaria fimiseda and S. coprophila. In De Bary's Beitr. z. Morph. u. Phys. d. Pilze, 3. Reihe, Taf. II-VI. (187o.)

47. Zopf, W.: In Sitzungsber. d. Botan. Vereins d. Prov. Brandenburg, Aug. 1874, pp. 125-1 26 (Verh. xvi). (1874.)

48. — In Sitzungsber. d. Naturf.-Freunde, Berlin, I88o, Feb. I7, pp. 2934. (1880.)

49. Zur Entwickelungsgesch. der Ascomycet. (Chaetomium). Nova Acta K. Leop.-Car. Akad., xlii, 199-292, Taf. XIV-XX. (I88ז.)

50. Zukal, H. : Mykolog. Untersuch. Denkschr. d. k. Akad. Wissensch., Math.Naturw. Classe, li, Abth. 2, pp. 2I-36, Taf. I-III. (I886.)

51. Ueber einige neue Pilze, Myx. u. Bakt. Verh. d. k. k. Zool.-Bot. Gesellsch., Wien, xxxv, 333-342, Taf. XV. (1886.)

52. Ueber einige neuen Ascomyceten. Ibid., xxxvii (Abhandl.), pp. 39-45, Taf. I. (1887.)

53. _- Entwickelungsgesch. Untersuch. aus dem Gebiete der Ascomycet. Sitzungsber. d. k. Akad. d. Wissensch., Wien, xcviii, Abth. I, pp. I-84, Taf. I-IV. (I 889.)

54. Ueber einige neue Pilzformen u. über das Verhältniss der Gymnoascen $z \mathfrak{u}$ den übrigen Ascomyceten. Ber. d. Deutsch. Bot. Gesellsch., viii, 295-303, Taf. XVII. (1890.)

\section{EXPLANATION OF FIGURES IN PLATES XVII AND XVIII.}

Illustrating Messrs. Massee and Salmon's paper on Coprophilous Fungi.

Fig. I. Sporormia longipes, sp. nov.; perithecium, $\times 45$; cells of outer wall of same, $\times 400$; two asci and spores, $\times 400$.

Fig. 2. S. pulchella, Hans.; perithecium, $\times 64$; cells of outer wall of same,

$\times 400$; two asci and spores, $\times 400$.

Fig. 3. Sporormiella nigropurpurea, Ell. and Everh.; group of three perithecia,

$\times 70$; two asci, paraphyses, and spores, $\times 400$.

Fig. 4. Sporormia ovina (Desmaz.), Sacc.; perithecium, $\times 80$; two spores, $\times 400$.

Fig. 5. Sordaria Winteri, Karst.; perithecium, $\times 40$; spore, $\times 400$.

Fig. 6. S. anserina (Rabenh.), Wint.; perithecium, $\times 25$; spore, $\times 400$.

A a 2 
Fig. 7. S. hirta, Hans.; perithecium, $\times 25$; spore, $\times 400$.

Fig. 8. S. coprophila, Ces. and De Not.; four stages in the development of the spore, $\times 400$ (see p. 315 ).

Fig. 9. S. macrospora, Auersw.; perithecium, $\times 25$; apex of ascus and two spores, $\times 400$.

Fig. Io. S. fimicola (Rob.), Ces. and De Not.; spore, $\times 400$.

Fig. II. S. minima, Sacc. and Speg.; perithecium, $\times 200$; ascus and two spores, $\times 400$.

Fig. I 2. S. curvicolla, Wint.; perithecium, $\times 25$; two spores, $\times 400$.

Fig. I3. S. setosa, Wint.; perithecium, $\times 25$; ascus, $\times 255$; spores, $\times 400$.

Fig. 14. S. pleiospora, Wint.; perithecium, $\times 25$; two spores, $\times 400$.

Fig. I5. S. neglecta, Hans.; perithecium, $\times 25$; spore, $\times 400$.

Fig. I6. S. fimiseda, Ces. and De Not., var. appendiculata (Auersw.); perithecium, $\times 25$; three spores, (a) young stage, $\times 400$.

Fig. I 7. Sordaria, sp. (see p. 34I); perithecium, $\times 25$; single cell of outer wall of same, $\times 400$.

Fig. I8. Delitschia moravica, Niessl. ; perithecium, $\times 80$; two spores, $\times 400$; single spore, $\times 670$.

Fig. 19. Sporormia fimetaria, De Not.; perithecium, $\times 80$; cells of outer wall of same, $\times 400$; ascus and spores, $\times 400$.

Fig. 20. Delitschia insignis, Mout.; perithecium, $\times 10$ and 30 ; spores, $\times 400$.

Fig. 21. Sordaria globosa, sp. nov.; perithecium, $\times 25$; spore, $\times 400$.

Fig. 22. Delitschia Winteri, Plowr.; perithecium, $\times 25$; spore, $\times 400$.

Fig. 23. Sphaeroderma fimbriatum, Rostr.; perithecium, $\times 4^{\circ}$; cells of outer wall of same, $\times 400$; ascus and spores, $\times 400$; to right, two hairs surrounding the ostiolum, $\times 400$.

Fig. 24. Microascus variabilis, sp. nov.; two perithecia, $\times 95$; cells of outer wall of perithecium and seta-like hair from same, $\times 400$; spores, $\times 400$; ascus and spores, $\times 670$; single spore, $\times 1000$.

Fig. 25. Pleuroascus Nicholsoni, gen. nov. sp. nov.; perithecium separated from the subiculum, and showing the spiral appendages attached to it, $x 80$; cells of outer wall of same, $\times 400$; spiral appendage, $\times 400$; ascus and spores (a) $\times 400,($ b) $\times 670,(c) \times 1000$.

Fig. 26. Magnusia Bartlettii, sp. nov.; perithecium, $\times 45$; cells of outer wall of same, $\times 400$; asci and spores, $\times 400$.

Fig. 27. Spumatoria longicollis, gen. nov. sp. nov. ; perithecium ejecting spores, $\times 90$; hyphae surrounding ostiolum, $\times 400$; cells of outer wall of basal part of perithecium, $\times 400$; ascus and spores, $\times 400$; to left of perithecium five stages in the development of the conidia (Rhyncophoma stage), $\times 400$.

Fig. 28. Eurotium microsporum, sp. nov. ; perithecium, $\times 45$; cells of outer wall of same, $\times 400$; two spores, $\times 980$; group of asci, $\times 1000$.

Fig. 29. E. insigne, Wint.; perithecium, $\times 25$; to left, cells of outer wall of same, $\times 400$; ascus and spores, $\times 400$; single spore, $\times 670$.

Figs. 30-32. Myxotrichum uncinatum (Eidam), Schroet.; Fig. 30, single tuft growing on Rabbit-dung, $\times 5^{2}$; three spores from same, $\times 400$; ditto and ascus, $\times 670$; Figs. 31,32 , tuft growing on the dung of Patagonian Cavy, $\times 45$; spores from same, $\times 400$ and 670 ; Fig. 32, appendage proceeding from the vegetative mycelium, $\times 400$.

Figs. 33-34. Rhyparobius ascophanoides, Sacc.; Fig. 33, apothecium, seen from 


\section{Coprophilous Fungi.}

above, and in section, $\times 45$; Fig. 34 , ascus containing nearly ripe spores, and paraphyses, and two ripe spores, $\times 400$.

Fig. 35. Endomyces coprophilus, sp. nov., part of creeping mycelium with three ripe asci and one immature ascus, $\times 4.00$; ascus with four and eight spores, $\times$ I000.

Figs. 36-38. Melanospora discospora, sp. nov.; Fig. 36, perithecium ejecting spores, $\times 95$; Fig. 37 , young ascus, $\times 400$; Fig. 38 , ripe spores, $\times 400$.

Figs. 39-40. Eurotium insigne, Wint.; conidial stage (= Gliocladium penicilloides, Corda); Fig. 39, single conidiophore, $\times 95$; Fig. 40, apex of same, and conidia, $\times 400$.

Figs. 4I-44. Thelebolus stercoreus, Zukal; Fig. 4I, apothecium, with single protruding ascus, $\times \mathrm{I}_{2} 5$; Fig. $4^{2}$, ascus, showing mode of dehiscence (magnified); Figs. 43, 44, apex of same, more highly magnified.

Fig. 45. 'Ascozonus oligoascus, Heimerl' (see p. 327); apothecium, $\times 255$, and ascus, $\times 400$.

Figs. 46, 47. Ryparobius, sp. on Goose-dung, Kew (see p. 320); apothecium, $\times 200$; two asci from the same apothecium, $\times 400$.

Figs. 48-51. Saccobolus quadrisporus, sp. nov.; Fig. 48, apothecium, $\times 5^{2}$; Fig. 49, ascus, $\times 400$; Fig. 50 , group of spores, discharged from the ascus, but still surrounded by the mucilaginous 'sac,' $\times 400$; Fig. 5 I, spores, $\times 670$.

Figs. 52-55. Ascobolus perplexans, sp. nov.; Fig. 52, ascophore, $\times 25$; Fig. 53 , ascus and paraphyses, $\times 400$; Fig. 54, spores, $\times 400$; Fig. 55, single spore, $\times 1000$.

Fig. 56. Two spores of Ascobolus glaber (A. albidus, Crouan), taken direct from apothecia growing on Rabbit-dung, and germinating in a hanging-drop of dung-decoction, $\times 400$ (see p. 317).

Figs. 57-61. Sphaeroderma Hulseboschii, Oudem.; Fig. 57, perithecium, $\times 5^{2}$; Fig. 58 , cells of outer wall of same, $\times 400$; Fig. 59 , ostiolum of perithecium, $\times 400$; Fig. 60, ascus and spores, $\times 400$; Fig. 61, immature spore, $\times 400$.

Figs. 62-65. Microascus nidicola, sp. nov.; Fig. 62, perithecium, $\times 95$; Fig. 63 , cells of outer wall of same, $\times 400$; Fig. 64 , asci and spores, $\times 400$; Fig. 65 , ditto, $\times 6$ 7o.

Fig. 66. Thelebolus stercoreus, Zukal; transverse section through an apothecium containing two asci, $\times 400$. 
Annals of Botany.

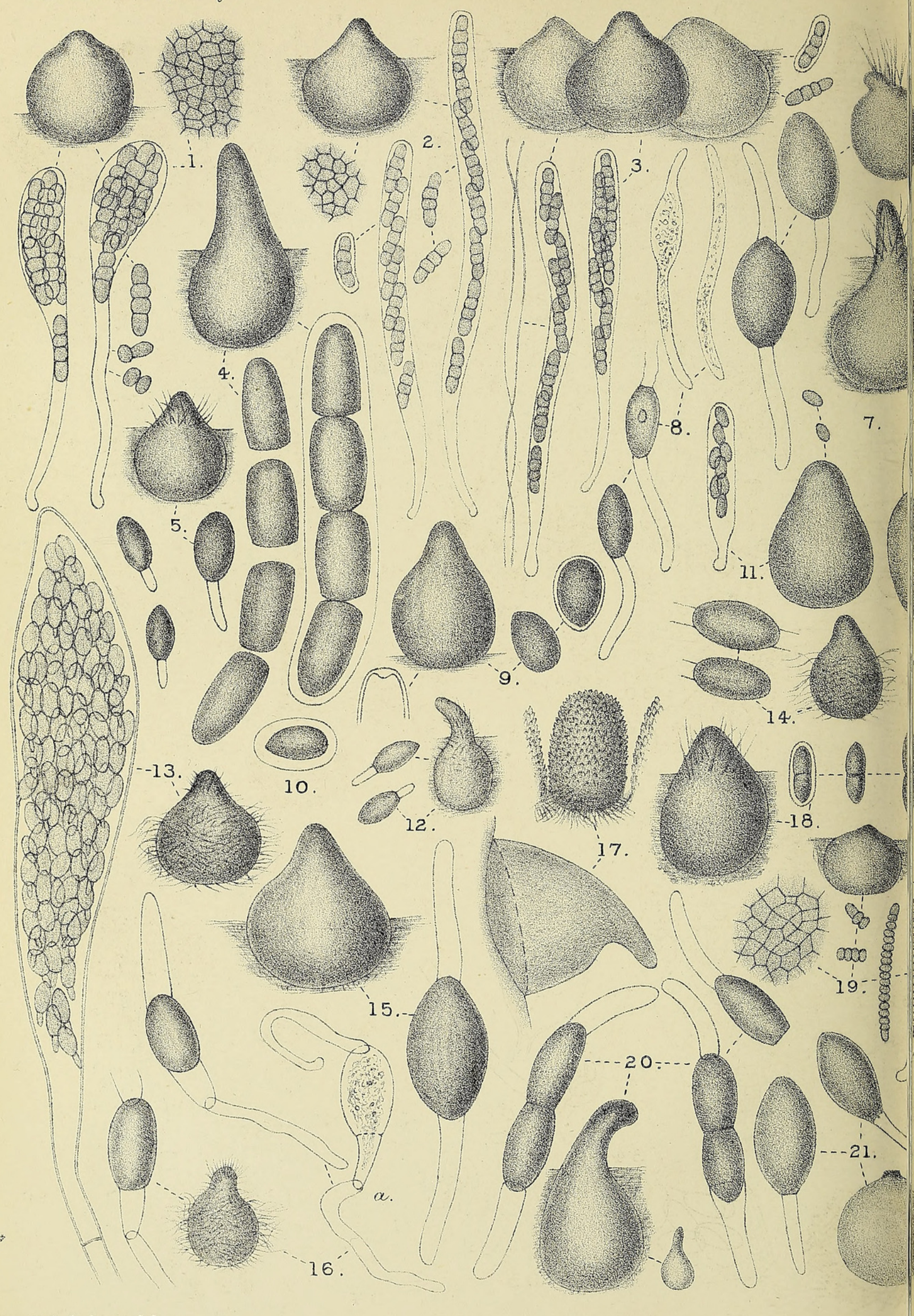



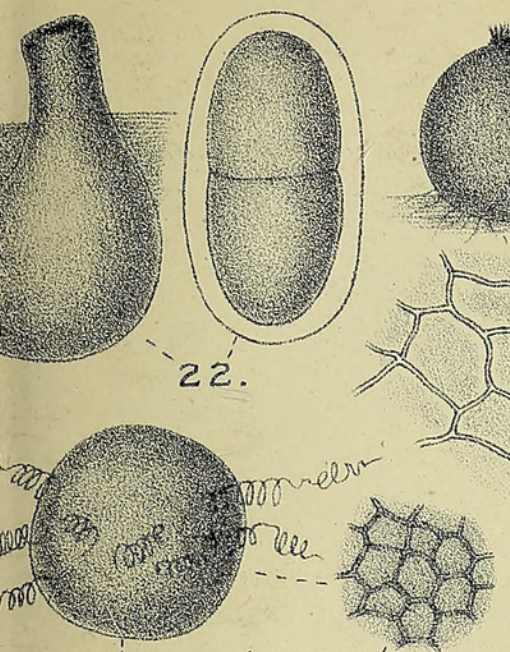

22

(2)

(2)
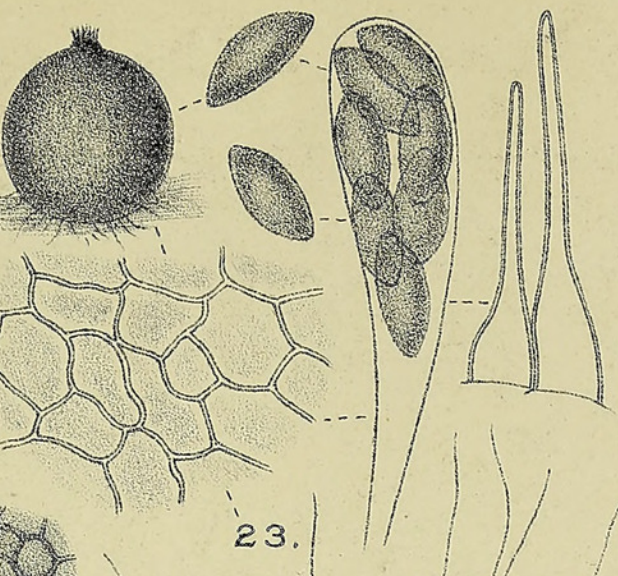

1

(1-2) - .
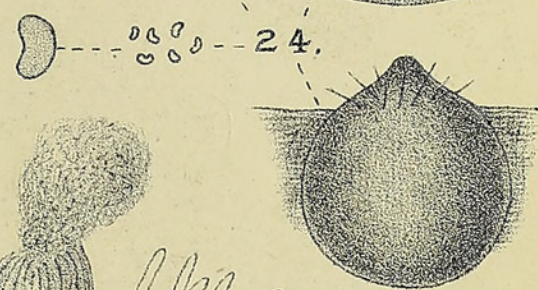

(28)

$+2$

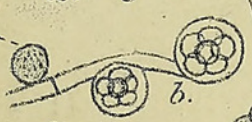

(83)
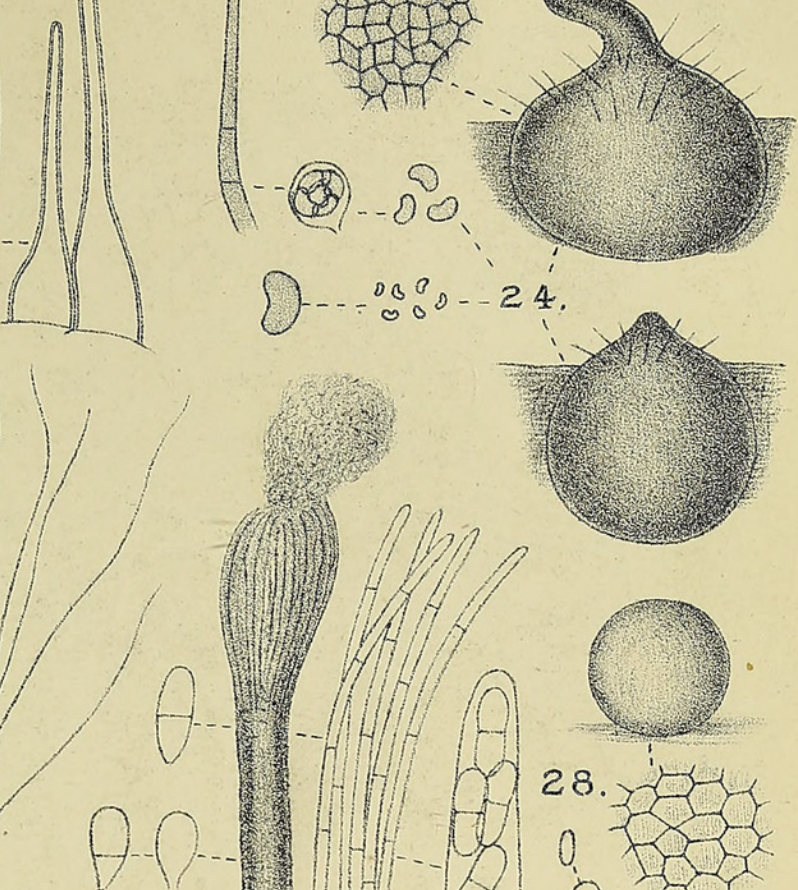

.

8

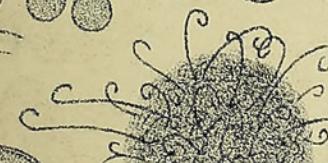

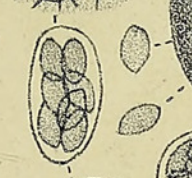

a $\sigma^{6} 6 / 27 \%$

fincs

centifon

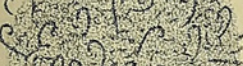

(rotrins $=2$

$0 .-31$

은?
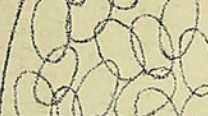

$100^{\prime}$
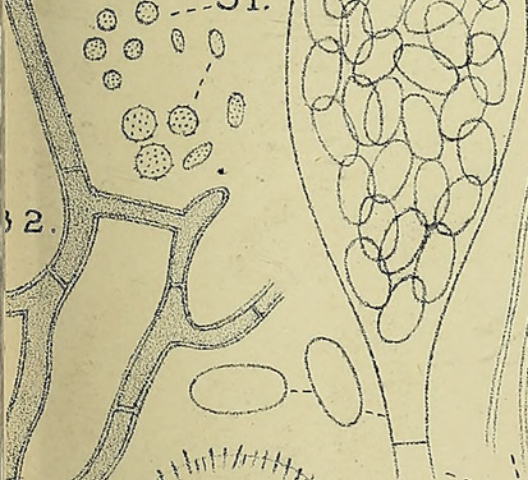

(3) (8) उसर

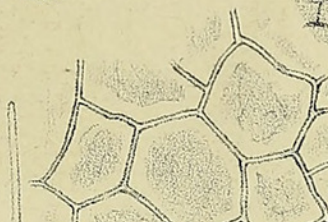
4

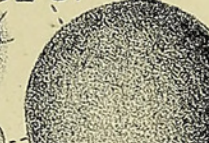

(1) HAt
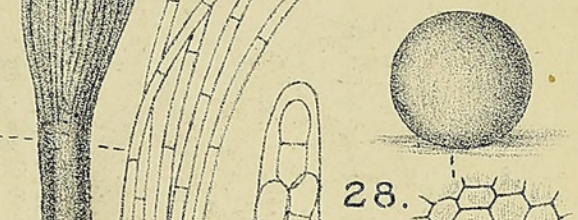

28. 7

0 सिरेख

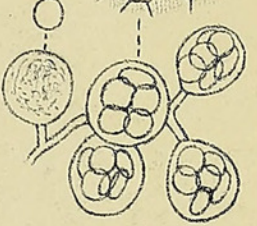

V

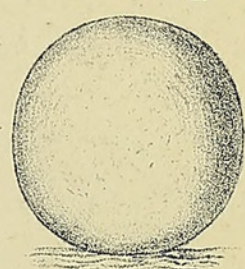

$-27 .-$
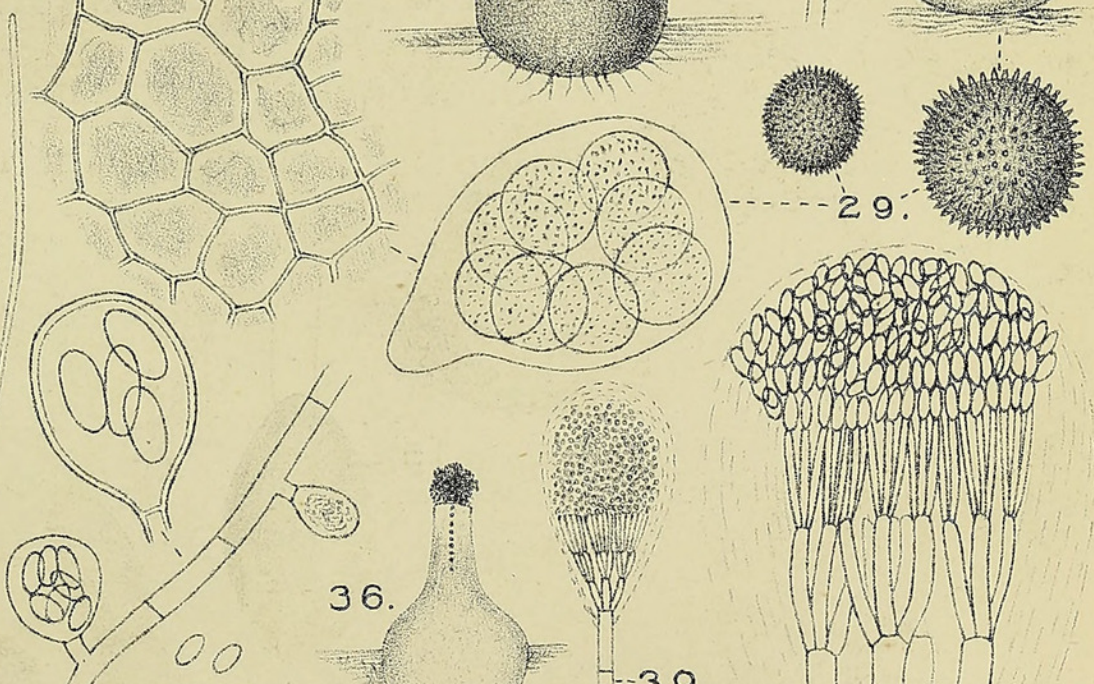

34.
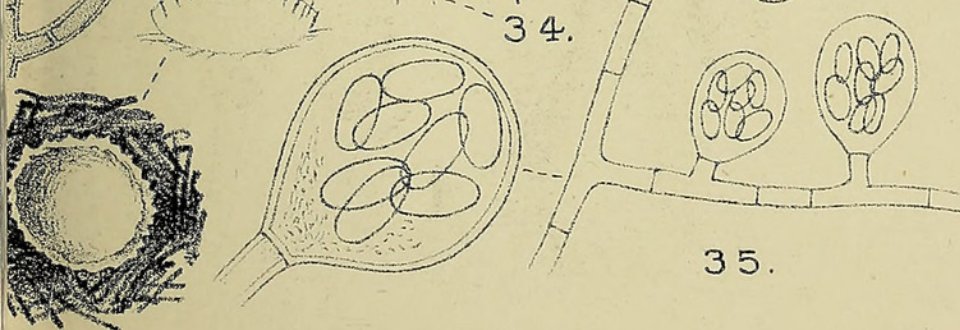

$-39$.

2.

40.

37.

100

33. 


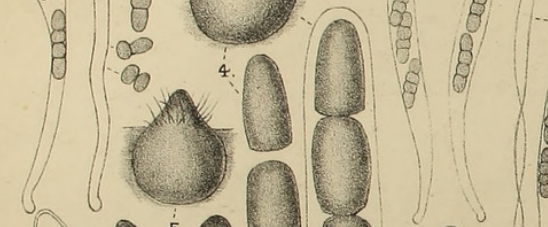

00
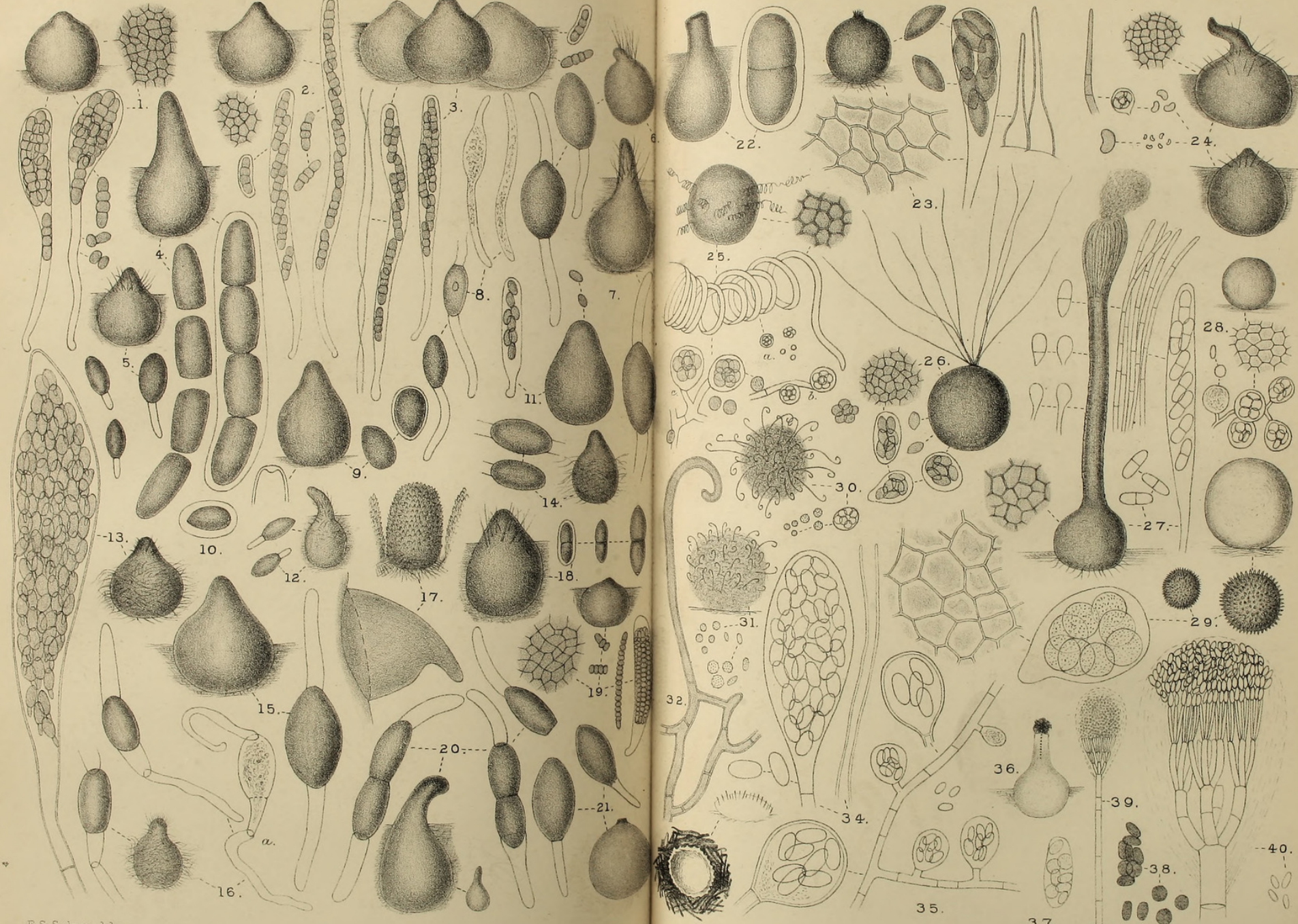

$10 \cdot 1: 90$

58
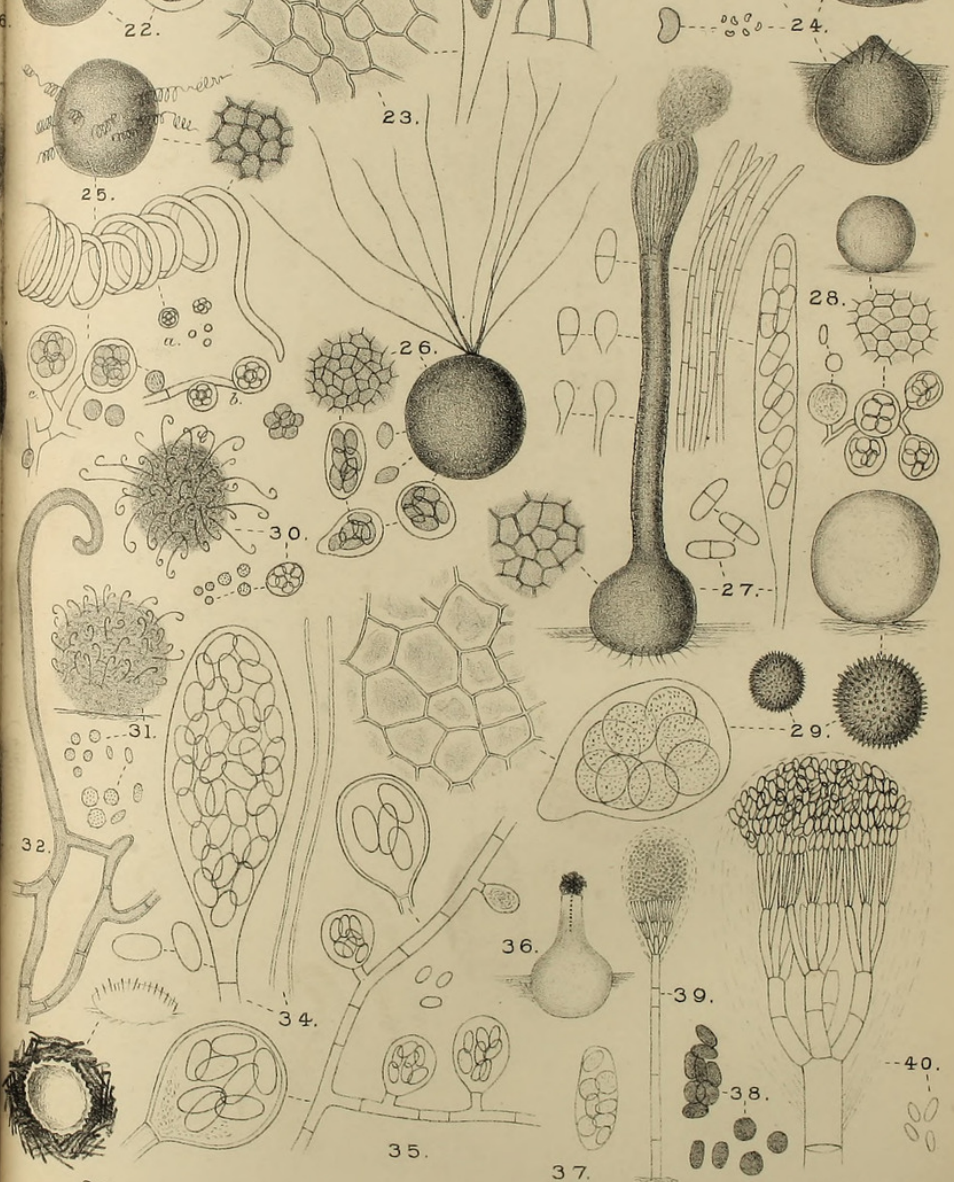

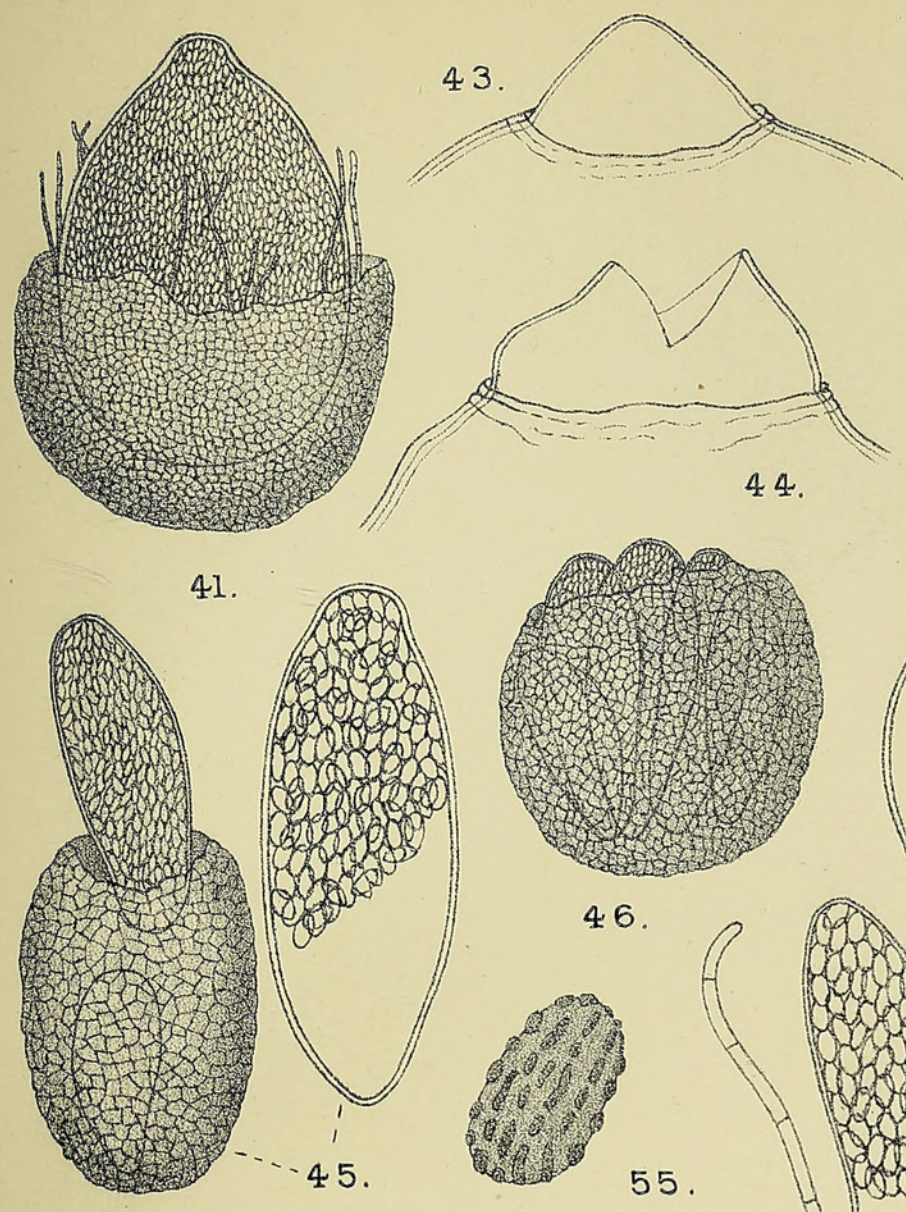

45.

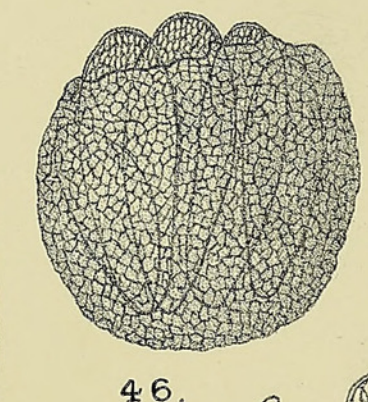

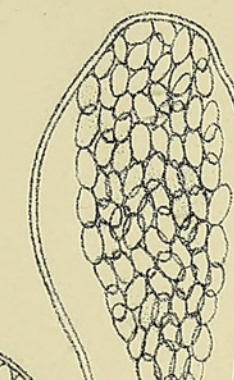

42.
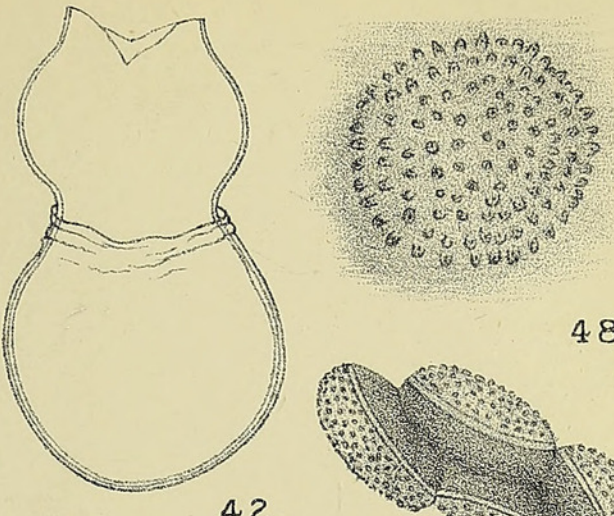

48.
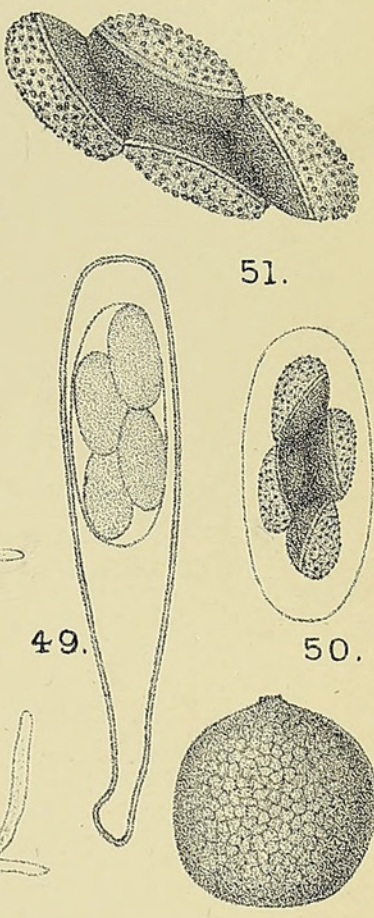

57.

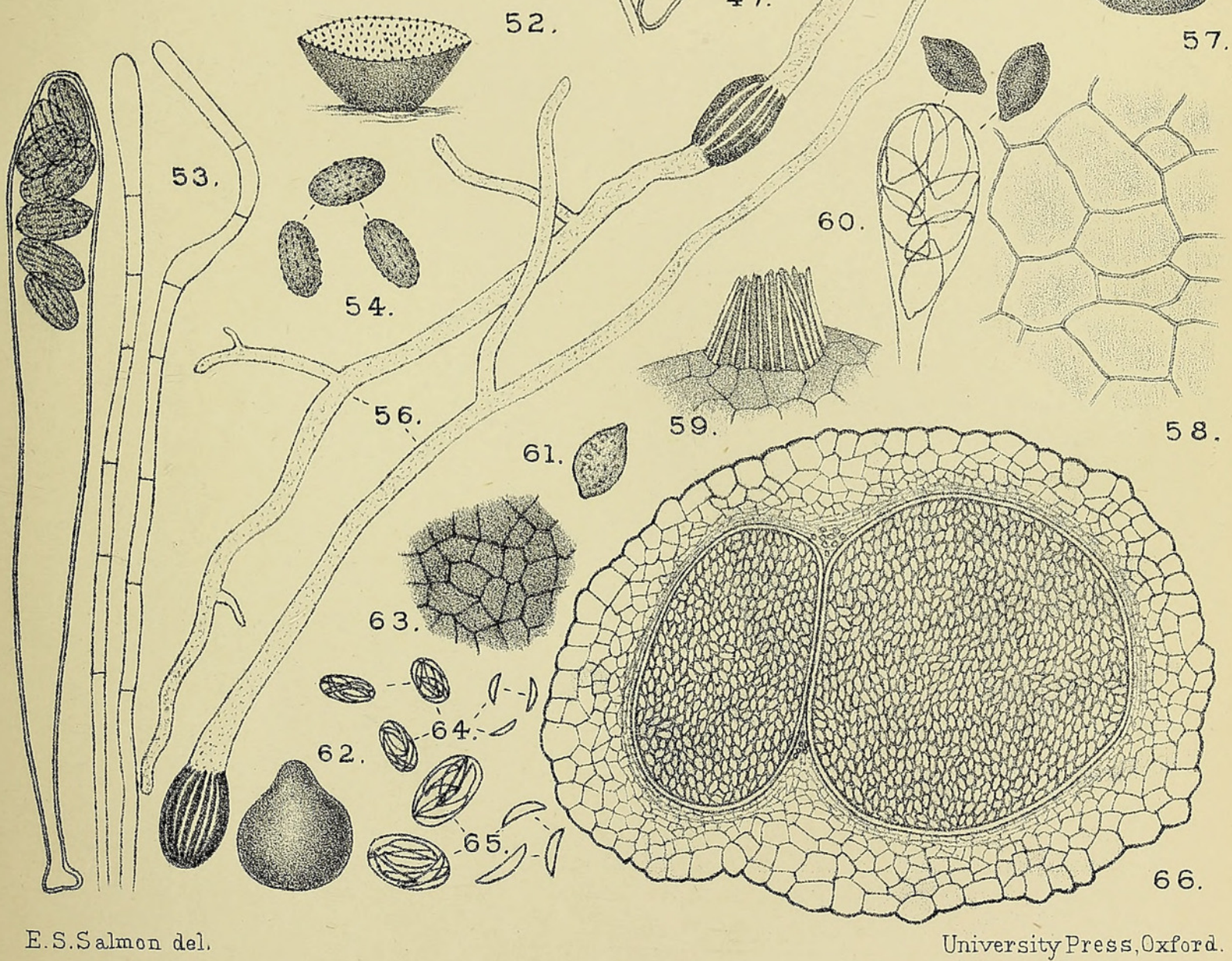

MASSEE \& SALMON - COPROPHILOUS FUNGI 


\section{$2 \mathrm{BHL}$ Biodiversity Heritage Library}

Massee, George and Salmon, Ernest Stanley. 1901. "Researches on coprophilous fungi." Annals of botany 15, 313-357. https://doi.org/10.1093/oxfordjournals.aob.a088820.

View This Item Online: https://www.biodiversitylibrary.org/item/236929

DOI: https://doi.org/10.1093/oxfordjournals.aob.a088820

Permalink: https://www.biodiversitylibrary.org/partpdf/318624

\section{Holding Institution}

Smithsonian Libraries

\section{Sponsored by}

Biodiversity Heritage Library

\section{Copyright \& Reuse}

Copyright Status: Not in copyright. The BHL knows of no copyright restrictions on this item.

This document was created from content at the Biodiversity Heritage Library, the world's largest open access digital library for biodiversity literature and archives. Visit BHL at https://www.biodiversitylibrary.org. 